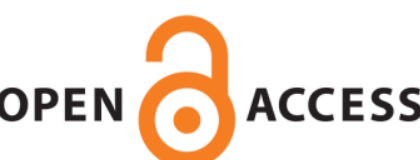

UWS Academic Portal

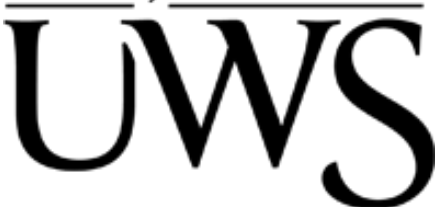

\title{
Experimental cyclic performance of cold-formed steel bolted moment resisting frames
}

McCrum, Daniel P.; Simon, Jordan; Grimes, Michael; Broderick, Brian M.; Lim, James B.P.; Wrzesien, Andrzej M.

Published in:

Engineering Structures

DOI:

10.1016/j.engstruct.2018.11.063

Published: 15/02/2019

Document Version

Peer reviewed version

Link to publication on the UWS Academic Portal

Citation for published version (APA):

McCrum, D. P., Simon, J., Grimes, M., Broderick, B. M., Lim, J. B. P., \& Wrzesien, A. M. (2019). Experimental cyclic performance of cold-formed steel bolted moment resisting frames. Engineering Structures, 181, 1-14. https://doi.org/10.1016/j.engstruct.2018.11.063

\section{General rights}

Copyright and moral rights for the publications made accessible in the UWS Academic Portal are retained by the authors and/or other copyright owners and it is a condition of accessing publications that users recognise and abide by the legal requirements associated with these rights. 
Title: Experimental cyclic performance of cold-formed steel bolted moment resisting frames

Author: Daniel P. McCrum ${ }^{1}$, Jordan Simon ${ }^{2}$, Michael Grimes ${ }^{2}$, Brian M. Broderick ${ }^{2}$, James B.P. Lim ${ }^{3}$, Andrzej M. Wrzesien ${ }^{4}$

Affiliations: 1 - School of Civil Engineering, Newstead Building, University College Dublin, Dublin 4, Ireland, 2 - Department of Civil, Structural \& Environmental Engineering, Museum Building, Trinity College Dublin, Dublin 2, Ireland, 3 - University of Auckland, 20 Symonds Street, Auckland 1010, New Zealand; 4 - School of Engineering and Computing, University of the West of Scotland, High Street, PA1 2BE, Paisley, United Kingdom;

\section{Corresponding Author: Daniel P. McCrum}

Corresponding Author Email: daniel.mccrum@ucd.ie

Corresponding Author Address: School of Civil Engineering, Newstead Building, University College Dublin, Dublin 4, Ireland

Abstract: This paper investigates the seismic performance of a single storey moment resisting cold-formed steel (CFS) portal frame through cyclic testing. Six monotonic and six cyclic tests were performed on three different section sizes of CFS. The portal frames were $3.2 \mathrm{~m}$ long $\mathrm{x}$ $2.2 \mathrm{~m}$ high and the CFS sections bolted with either perfect-fit tolerance bolt holes (PTBH) or normal tolerance bolt holes $(\mathrm{NTBH})$ connections. Connections with NTBH are standard in CFS, but connections with PTBH are often only used for short-spanning frames. Results from the tests demonstrated that both PTBH and NTBH connections had stable hysteresis and good hysteretic energy dissipation capacity and ductility. On average, the NTBH connections performed better under cyclic loading in comparison to the PTBH connections $(5.4 \%$ larger ductility and $22.3 \%$ increased energy dissipation). Strain gauge results show failure due to combined bending and bi-moment stresses, of which the bi-moment stress component accounted for $41 \%$ of the total longitudinal stresses at the section web. It should be noted that bi-moment stresses are often incorrectly ignored by practitioners; the experimental test results thus show that by doing so the sections would fail at $59 \%$ of the design moment. Initial failure was localised at the top of the column sections in the form of local buckling at the web-toflange junction under compressive stresses. Several load cycles past the initial buckling stage led to a further reduction of steel ductility due to strain hardening and strain ageing leading to 
fracture of the steel in the section corners. The buckling/tearing failure in the columns would result in a reduced axial load carrying capacity.

Keywords: Cold-formed steel portal frames; Cyclic testing; Moment resisting frame; Connections with perfect-fit tolerance bolt holes; Connection with normal tolerance bolt holes

\subsection{Introduction}

Cold-formed steel (CFS) structures can perform well in seismic conditions; however, their seismic performance has historically not received significant investigation. The design of CFS structures is not covered by Eurocode 8 [1] and therefore, no behaviour factor, $q$, is provided for this class of structure. This results in CFS structures being classified as non-dissipative structures and therefore can be perceived as not being suitable in seismic design. Therefore, design guidance is required for earthquake resistant design of CFS structures and subsequently, designers can only rely on static design guidance [2\&3].

In the past decade, however, research into the seismic response of CFS structures has received more attention. One aspect of the good seismic performance of CFS structures is the low levels of loading (e.g. domestic dwellings) that result in low inertia forces compared to standard construction materials (e.g. masonry, reinforced concrete, hot rolled steel). However, the main reason for the good seismic performance of CFS structures is their redundancy and the overstrength of typical CFS stud wall type construction [4]. CFS stud wall type construction is commonly used in domestic dwellings.

A considerable amount of research has been undertaken to investigate the cyclic performance of CFS shear walls [5-8] or CFS strapped braced walls [9]. Researchers have also investigated the cyclic performance of the connections of shear walls to plasterboard [10] and sheeting [11]. These types of structure are typical of domestic housing and have significant redundancy due to the multiple studding elements and connection to sheeting elements.

Most of the cyclic testing of CFS moment resisting structures has not focussed on the full frame, however, focused solely on the moment resisting connections [12-14]. Few researchers have studied the seismic performance of CFS moment resisting frames [15\&16]. Kabhir et al., [16] investigated the cyclic performance of a half-scaled CFS portal frame constructed with box column sections and back to back channel section beams. The authors found from experimental and analytical results that the frame experienced failure at the top and bottom of the columns (local buckling, but not tearing). The results indicated that the CFS frames had a buckling failure mode in the columns. Li et al., [15] performed monotonic and cyclic tests on 
a duo-pitched CFS portal frame. They observed that failure was due to local buckling of the column base followed by local buckling of the column to rafter connection. After local buckling, the columns axial load carrying capacity reduces. Overall, the results of the tests showed the frame had a ductility of 3.15 with no significant degradation of stiffness and strength throughout the cyclic tests. No purlins or sheeting was tested, only the structural frame.

In this paper, the cyclic performance of both perfect-fit tolerance bolt hole (PTBH) (bolt hole tolerance $\approx 0.0 \mathrm{~mm})$ and normal tolerance bolt hole $(\mathrm{NTBH})($ section bolt hole tolerance $=$ $2.0 \mathrm{~mm}$ ) moment resisting connections within the full-scale $2.2 \mathrm{~m}$ high by $3.2 \mathrm{~m}$ long portal frame is investigated. Three different frame back-to-back sections were investigated; $203 \times 76 \times 20 \mathrm{~mm}$ (1.8mm thick), 254x76x20mm (2.0mm thick) and 300x95x20mm $(2.5 \mathrm{~mm}$ thick). All bolts are $16 \mathrm{~mm}$ in diameter. In order to prevent frames in-plane displacement beyond the actuator stroke, $1 \mathrm{~mm}$ hole tolerances were used in the bracket plates. This adds up to a combined maximum slip of $3 \mathrm{~mm}$. It should be noted that it is CFS industry practice to supply both sections and brackets with $2 \mathrm{~mm}$ bolt holes tolerance. NTBH connections are standard for site-erected CFS structures, but the proper inclusion of the bolt slip in any analysis poses problems to designers. Connections with PTBH are not widely used in practice, but they were developed in the laboratory as a benchmark for NTBH connections. Perfect-fit connections, however, can be found in short span portal frames in which small diameter selfdrilling or self-tapping screws are used.

\subsection{Portal Frame Details}

In terms of the design of CFS portal frames under static loads, designers are given little normative guidance and must rely on test data. A recent design manual by [17], presents worked examples on the design of structural members in a CFS portal frame. The manual, however, offers no guidance on the joint design in terms of strength and stiffness. The bending moments in the worked example are calculated based on the assumption of rigid joints and impact of the semi-rigid joint on the frames deflections is not specified. It is common practice that a rigid joint assumption is used in industry to conduct both ultimate and serviceability limit state checks which often contradict with provisions given by [18]. However, here the joints moment resisting capacity is based on the local buckling of the channels web due to combined bending and bi-moment considered in the strength prediction [19]. The joint rotational stiffness was modelled as bi-linear spring using a maximum $3 \mathrm{~mm}$ slip of bolts in tolerance holes [20] and the Elastic Method for In Plane Eccentrically Loaded Connections [21] was used for 
predicting rotational stiffness of the bolt-group in the bearing phase of loading. The shear stiffness of the lap connection was calculated using analytical formula after [22] and offered a conservative prediction of the maximum sway under monotonic load.

Exact dimensions of the channel sections used in the series of tests are as follows; $203 \times 76 \times 20 \mathrm{~mm}$ with $1.8 \mathrm{~mm}$ plate thickness (referred to as C20018), 254x76x20mm with $2.0 \mathrm{~mm}$ plate thickness (referred to as $\mathrm{C} 25020$ ) and $300 \times 95 \times 20 \mathrm{~mm}$ with $2.5 \mathrm{~mm}$ plate thickness (referred to as C30025). The grade of steel coil used for manufacturing sections is S450GD+Z275 according to [23] with nominal properties of $f_{y}=450 \mathrm{~N} / \mathrm{mm}^{2}(0.2 \%$ proof strength), $\mathrm{f}_{\mathrm{u}}=510 \mathrm{~N} / \mathrm{mm}^{2}$ (ultimate tensile strength) and nominal $14 \%$ non-proportional elongation at maximum force ( $80 \mathrm{~mm}$ gauge length). The mechanical properties of steel were also established by testing according to [24]. Tensile test results are presented in Table 1 and stress-strain curves for coupons of 1.8, 2.0 and 2.5mm thick are shown in Figure 1. In total, 12 tensile tests were carried out to determine mechanical properties of all steel gauges used for test components. The tensile coupons were cut out of steel channels and tested according to [24] using $20 \mathrm{~mm}$ wide coupons. Coupons were tested in the Instron universal testing machine using friction grips. A non-contact Advanced Video Extensometer (AVE 2663-821) with 10 $\mathrm{mm}$ gauge length was used to measure the longitudinal strain. Each steel gauge (1.8, 2.0, 2.5 \& $3.0 \mathrm{~mm}$ (the haunch bracket was $3.0 \mathrm{~mm}$ thick)) was tested 3 times and final results were taken as average as shown in Table 1 and Figure 1. The details of the dimensions and construction of the C20020 portal frame is shown in Figure 2. No secondary structure or cladding was tested in the experimental programme, only the moment resisting frame.

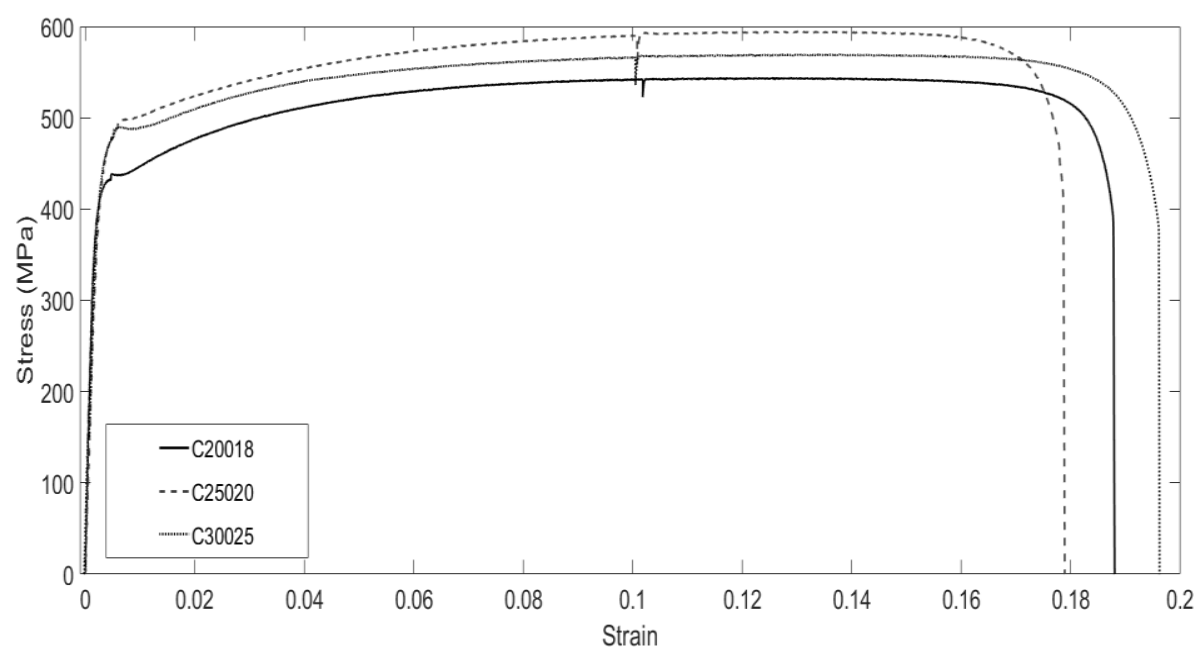

Figure 1. Stress-strain tensile test plots for flat portion of web for; $\mathrm{C20018}, \mathrm{C25020}$ and $\mathrm{C30025}$ 
Table 1. Tensile test results for $\mathrm{C20018,} \mathrm{C} 25020$, and $\mathrm{C30025}$ coupons

\begin{tabular}{c|c|c|c|c|c|c}
\hline Component & Position & $\begin{array}{c}\text { Number } \\
\text { of } \\
\text { tensile } \\
\text { tests }\end{array}$ & $\begin{array}{c}\text { Average proof } \\
\text { strength, } \\
\mathbf{R}_{\mathbf{p}, \mathbf{0 . 2}} \\
\mathbf{( M P a})\end{array}$ & $\begin{array}{c}\text { Average tensile } \\
\text { strength, } \\
\mathbf{R}_{\mathbf{m}} \\
(\mathbf{M P a})\end{array}$ & $\begin{array}{c}\text { Non- } \\
\text { proportional } \\
\text { elongation at } \\
\text { max. stress, } \\
\mathbf{A}_{\mathbf{g}, \mathbf{t}}(\boldsymbol{\%})\end{array}$ & $\begin{array}{c}\text { Elongation } \\
\text { after } \\
\text { fracture, } \mathbf{A}_{\mathbf{t}} \\
(\boldsymbol{\%})\end{array}$ \\
\hline $\mathrm{C} 20018$ & $\begin{array}{c}\text { Flat portion } \\
\text { of a web }\end{array}$ & 3 & 457 & 543 & 13 & 19 \\
\hline C25020 & $\begin{array}{c}\text { Flat portion } \\
\text { of a web }\end{array}$ & 3 & 482 & 596 & 13 & 19 \\
\hline C30025 & $\begin{array}{c}\text { Flat portion } \\
\text { of a web }\end{array}$ & 3 & 475 & 573 & 12 & 19 \\
\hline FHB300B & $\begin{array}{c}\text { Flat portion } \\
\text { of a web }\end{array}$ & 3 & 489 & 546 & 12 & 19 \\
\hline
\end{tabular}

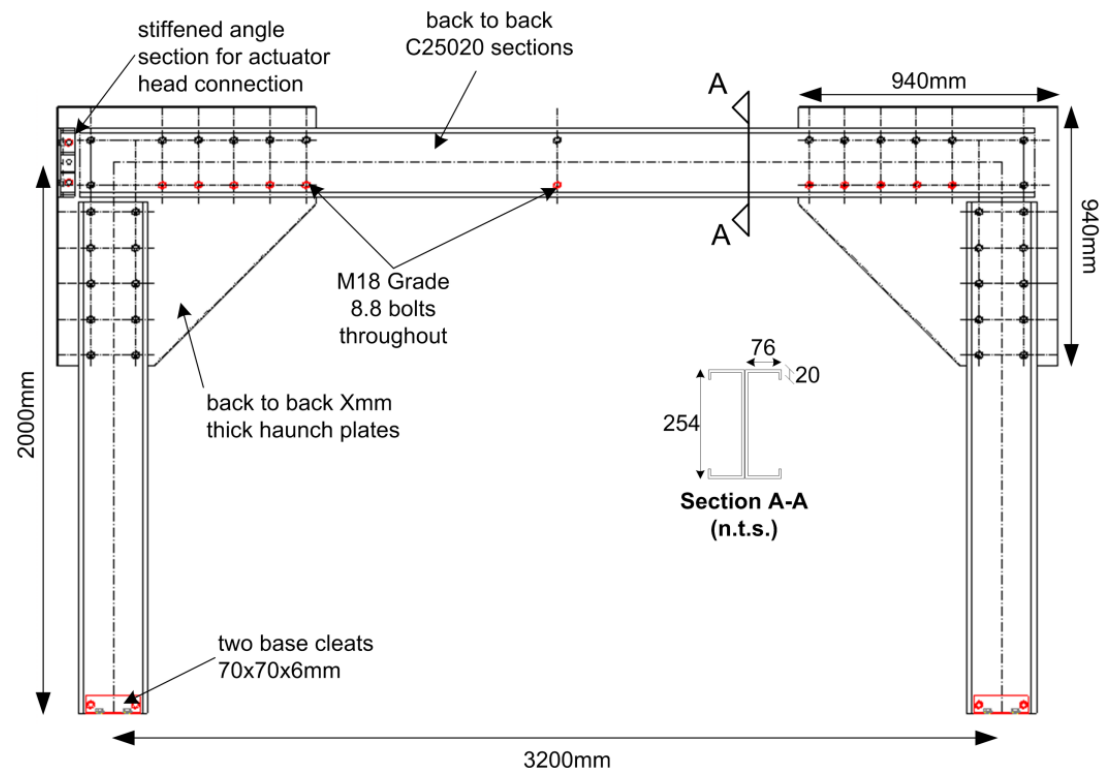

Figure 2. Schematic of $\mathbf{C 2 5 0 2 0}$ portal frame with PTBH connection

The NTBH connections have $17 \mathrm{~mm}$ diameter holes in the brackets and $18 \mathrm{~mm}$ diameter holes in sections with $16 \mathrm{~mm}$ diameter bolts. The PTBH connections have $18 \mathrm{~mm}$ diameter bolt holes for $18 \mathrm{~mm}$ diameter bolts. The bracket thickness for all the haunch connections is $3 \mathrm{~mm}$. Figure 3 shows the haunched connection and the base plate connection. There are five pairs of bolts connecting each column and six pairs of bolts connecting each beam to the haunch plate. The column and beam sections are formed from two back-to-back CFS channel sections as shown in Section A-A in Figure 2.

One of the aims of the testing in this study is to understand the ductility and hysteretic energy dissipation capacity of the two connection types and how they impact on the overall cyclic performance. The ductility was calculated as the first yield lateral in plane displacement 
divided by the maximum lateral in plane displacement of the test frame. The method of calculating the first yield displacement is presented in Figure 6.
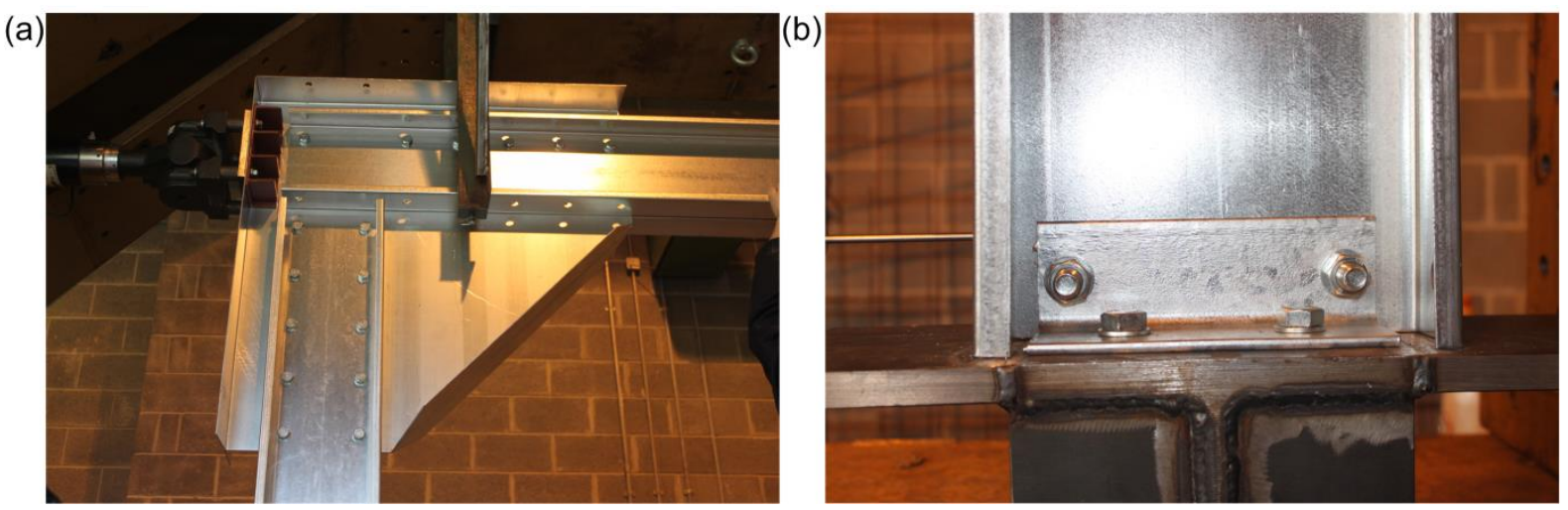

Figure 3. Photograph of; (a) beam/column and haunch connection; and (b) base plate connection for $\mathbf{C 2 5 0 2 0}$ test specimen 
(a)

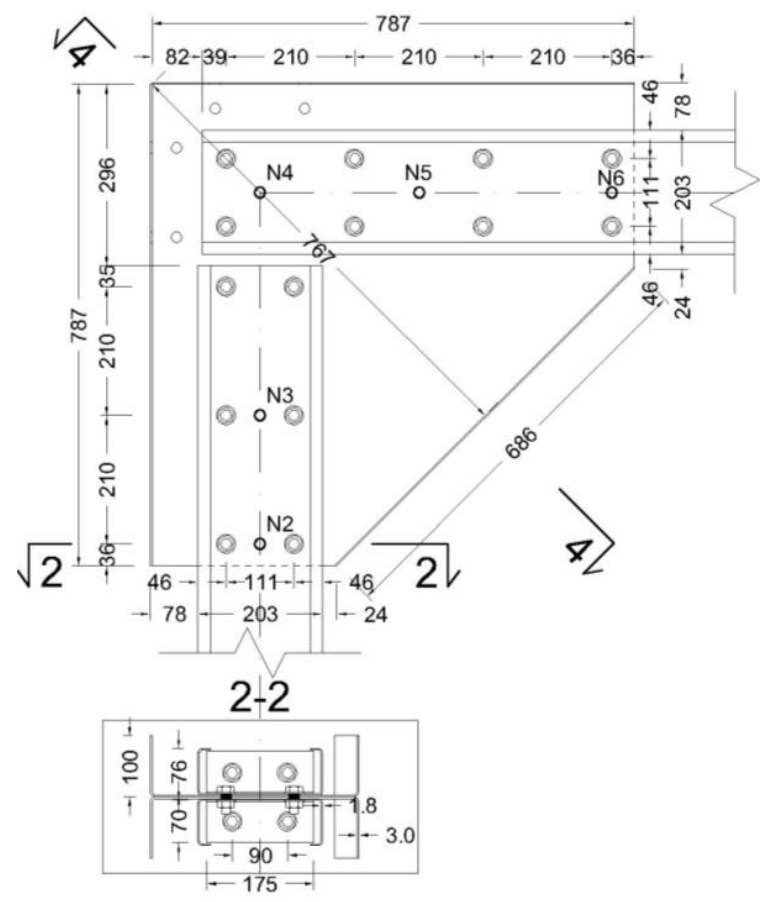

(b)



(c)

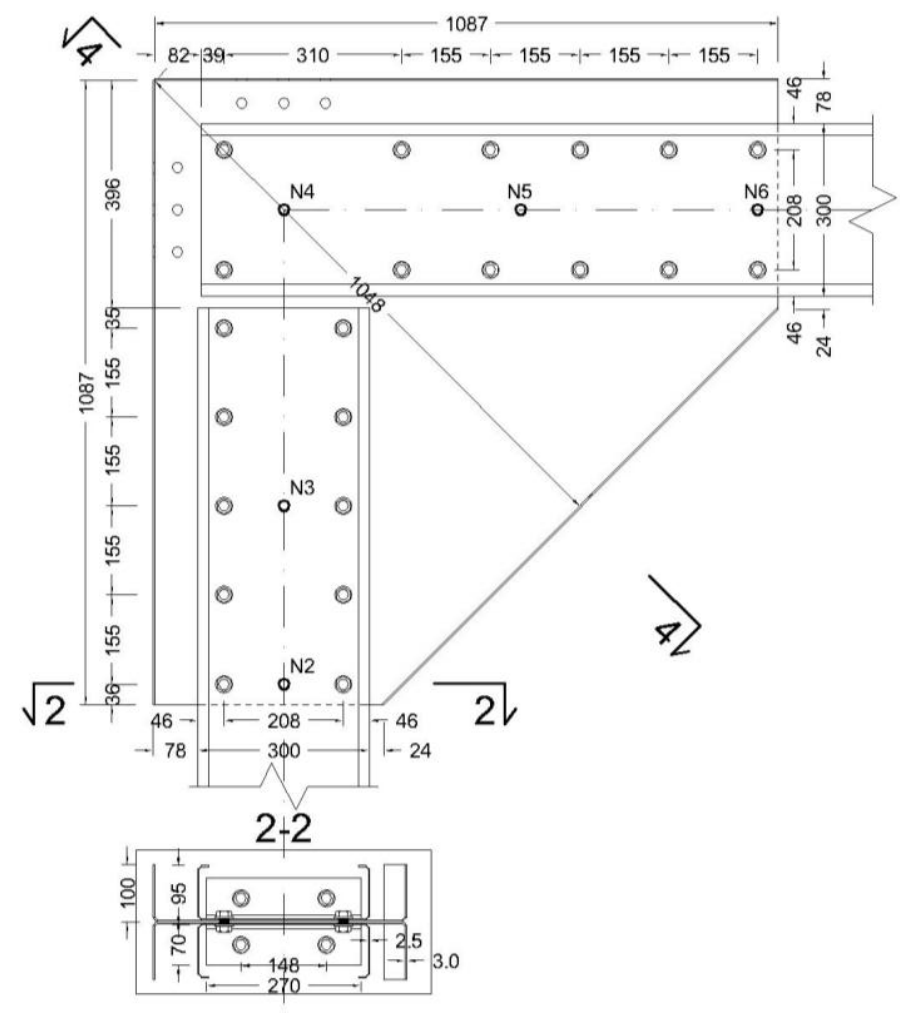

Figure 4. Schematic of bolt groups for; (a) C20018 haunch connection; (b) C25020 haunch connection; and (c) $\mathrm{C} 30025$ haunch connection 


\subsection{Experimental Set-up}

The experimental set-up consists of a CFS portal frame sandwiched between two back-to-back strong reaction frames as shown in Figure 5. Support beams span between the two reaction frames as shown in Figure 5(a). The test frame is then supported off these beams using universal column stub sections. The stub sections have small rotational stiffness and therefore replicate pinned connections. The actuator is mounted in between the two reaction frames as can be seen in Figures 5(a) \& (b). The actuator is a $150 \mathrm{kN}$ capacity high speed linear hydraulic actuator with a $250 \mathrm{~mm}( \pm 125 \mathrm{~mm})$ stroke. The actuator has an internal load cell and linear variable differential transducer (LVDT) to measure the actuator head in-plane displacement. During each test, the force and displacement of the actuator head are recorded on an actuator controller PC. In order to prevent out-of-plane displacement of the test frame during the experiments, two lubricated roller guides hold the test frame in place whilst allowing the test structure to move 'frictionless' in the plane (see Figure 5). Force was measured by a load cell at the roller guide closest to the actuator head. Every connection bolt was tightened with a torque wrench to the value of $90 \mathrm{Nm}$. The tightening torque value of $90 \mathrm{Nm}$ is an equivalent torque generated in practice by a typical hand spanner according to [24].
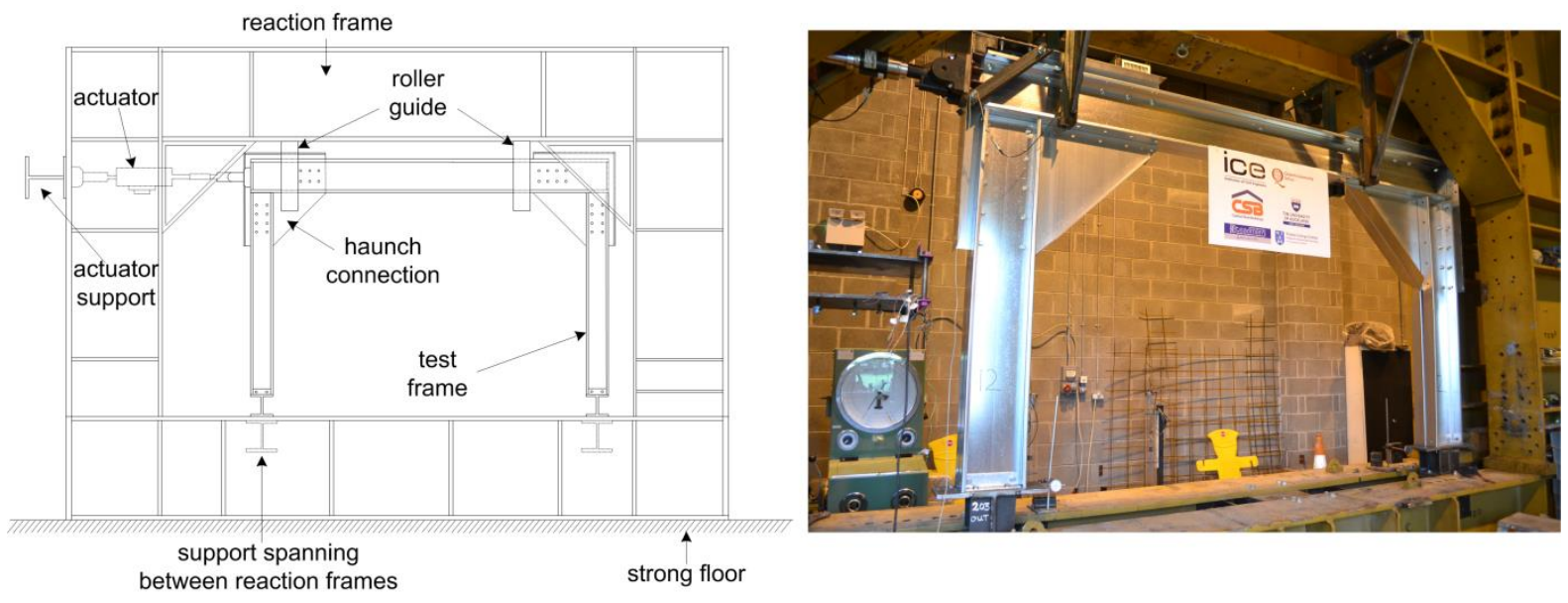

Figure 5. (a) Schematic of the experimental set-up; and (b) photograph of experimental set-up for C300 specimen showing back-by-back reaction frames with CFS portal frame and actuator in between the two reaction frames

\subsection{Experimental Programme}

\subsubsection{Monotonic Testing}

Initially, monotonic pushover tests of the portal frames were carried out as per the experimental programme in Table 2. In total, six monotonic pushover tests were performed, one on each 
section size and one on each connection type, as shown in Table 2. Figure 6 shows the monotonic pushover curves for the NTBH connection frames, namely; Tests $2,4 \& 6$. The monotonic pushover tests provided the capacity curve response along with parameters, such as first 'yield' point evaluated according to [26]. The first 'yield' point was then used to define the amplitude of the displacement cycles for the cyclic tests.

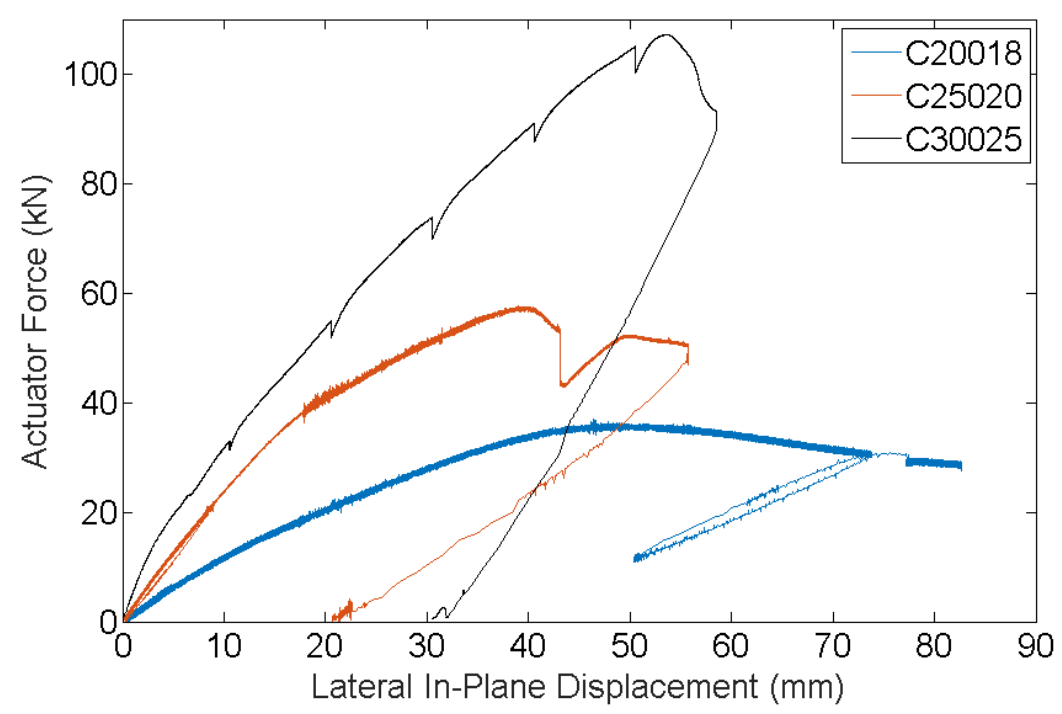

Figure 6. Actuator force vs lateral in-plane displacement monotonic pushover plots for NTBH bolted connections for; (a) C20018 frame (Test 2); (b) C25020 frame (Test 4); and (c) $\mathbf{C 3 0 0 2 5}$ frame (Test 6)

Table 2. Experimental programme for monotonic tests

\begin{tabular}{c|c|c|c|c}
\hline $\begin{array}{c}\text { Test } \\
\text { No. }\end{array}$ & $\begin{array}{c}\text { Test } \\
\text { type }\end{array}$ & Connection Type & $\begin{array}{c}\text { Connection } \\
\text { Member }\end{array}$ & Test Type \\
\hline 1 & C20018 & PTBH & FHB200A & Monotonic \\
2 & C20018 & NTBH & FHB200B & Monotonic \\
\hline 3 & C25020 & PTBH & FHB250A & Monotonic \\
4 & C25020 & NTBH & FHB250B & Monotonic \\
\hline 5 & C30025 & PTBH & FHB300A & Monotonic \\
6 & C30025 & NTBH & FHB300B & Monotonic \\
\hline
\end{tabular}

Figure 7 shows the capacity curve for Test 4 . In CFS structures, the first 'yield' point is difficult to evaluate as the failure is likely to occur due to local buckling of the web and flanges of the section. Therefore, a method is required to calculate the first 'yield' point for the cyclic tests using the procedure set out in the European Standard, ECCS (1986). This is done as follows; the initial stiffness, $K_{\mathrm{i}}$ is found from the slope of the tangent to the initial nonlinear portion of the capacity curve as shown in Figure 7 . The $K_{\mathrm{i}} / 10$ slope is calculated, and a tangent of this slope is aligned with the ultimate force $\left(F_{\text {ult }}\right)$ reached during the pushover test. Where the $K_{\mathrm{i}}$ 
and $K_{\mathrm{i}} / 10$ lines intersect (Point $\mathrm{A}$ in Figure 7) a line is extended vertically and where this line intersects the capacity curve (Point B in Figure 7) this is the first yield displacement, $\delta_{\mathrm{y}}$. Where this line intersects with the capacity curve a line is drawn horizontally. This value is the yield force, $F_{\mathrm{y}}$. The failure displacement of the test, $\delta_{\text {fail }}$, does not correspond to a failure of the test specimen but the point at which the test was stopped. It should be noted that unlike typical hotrolled portal frames, the tested CFS frame shows nonlinear load-displacement behaviour at lower levels of lateral displacement, which is very likely a result of bolt slip in connections. There were equipment issues with the recording of data from Test 3 and therefore, the yield displacement and failure load were not recorded as shown in Table 3. The initial stiffness was obtainable from the recorded data in Test 3. All other monotonic results are shown in Table 3.

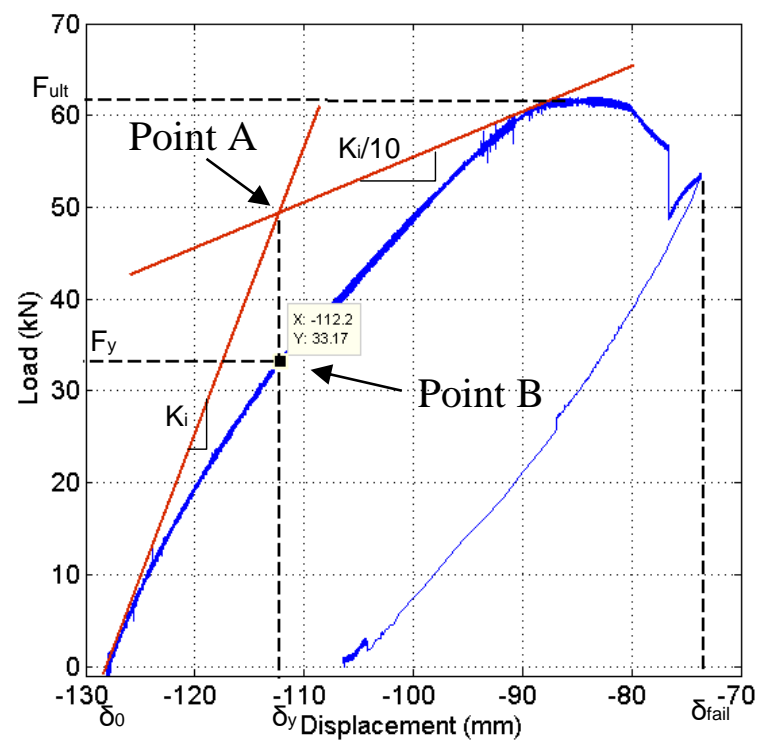

Figure 7. Portal frame capacity curve for Test 4 according to [26]

Table 3. Summary of monotonic experimental results

\begin{tabular}{c|c|c|c|c|c|c}
\hline $\begin{array}{c}\text { Test } \\
\text { No. }\end{array}$ & $\begin{array}{c}\mathbf{K}_{\mathbf{i}} \\
(\mathbf{k N} / \mathbf{m m})\end{array}$ & $\begin{array}{c}\mathbf{K}_{\mathbf{i}} / \mathbf{1 0} \\
(\mathbf{k N} / \mathbf{m m})\end{array}$ & $\begin{array}{c}\boldsymbol{\delta}_{\mathbf{y}} \\
(\mathbf{m m})\end{array}$ & $\begin{array}{c}\mathbf{F}_{\mathbf{y}} \\
(\mathbf{k N})\end{array}$ & $\begin{array}{c}\mathbf{F}_{\text {ult }} \\
(\mathbf{k N})\end{array}$ & $\begin{array}{c}\boldsymbol{\delta}_{\text {fail }} \\
(\mathbf{m m})\end{array}$ \\
\hline 1 & 1.20 & 0.120 & 21.8 & 19.73 & 31.6 & 45.2 \\
2 & 1.43 & 0.143 & 21.1 & 16.33 & 32.3 & 59.9 \\
\hline 3 & 2.58 & 0.258 & - & - & - & - \\
4 & 2.70 & 0.270 & 19.4 & 40.83 & 57.6 & 42.9 \\
\hline 5 & 5.06 & 0.506 & 17.47 & 58.55 & 105.3 & 37.2 \\
6 & 5.24 & 0.524 & 16.13 & 45.41 & 107.1 & 53.6 \\
\hline
\end{tabular}




\subsubsection{Cyclic Testing}

A series of cyclic tests were performed on virgin specimens following the monotonic tests in order to quantify the low cycle fatigue experienced by building structures during an earthquake. The series of cyclic tests were performed according to the European Standard, [26] with one cycle at $1 / 4 \delta_{\mathrm{y}}, 1 / 2 \delta_{\mathrm{y}}, 3 / 4 \delta_{\mathrm{y}} \& \delta_{\mathrm{y}}$ followed by three cycles at $2 \delta_{\mathrm{y}}$ and three cycles at $(2+2 \mathrm{n}) \delta_{\mathrm{y}}$ where $\mathrm{n}=1,2,3 \ldots$ The displacement controlled cycles are shown in Figure 8 . The value of $\delta_{\mathrm{y}}$ for each frame and connection type was found from the monotonic tests. The monotonic test results are summarised in Table 3. The cyclic tests were conducted at pseudo-static rates of loading, such that strain rate effects are not considered.

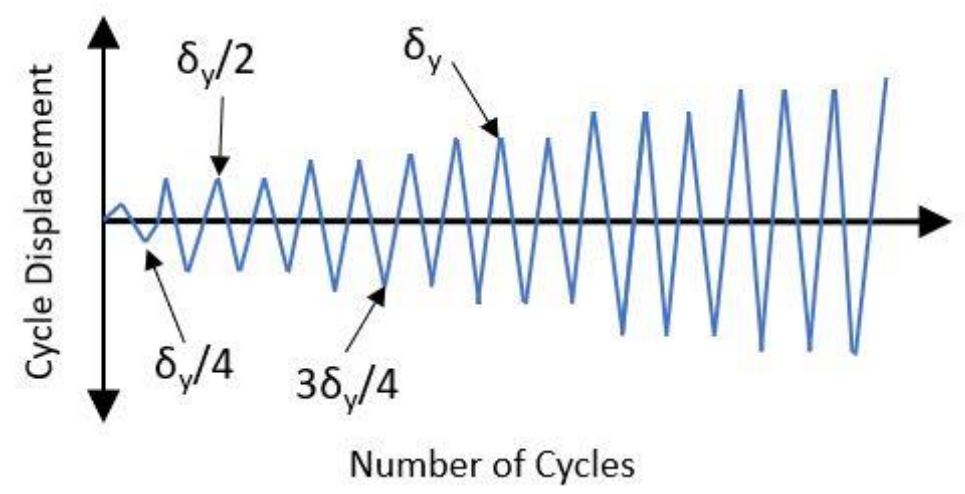

Figure 8. Load cycles for cyclic tests according to [26]

Six cyclic tests were performed as shown in Table 4. Two tests were to be performed on each portal frame section size, each of which would have either PTBH or NTBH haunch connections. The cyclic tests were run until failure was reached (e.g. $\delta_{\text {fail }}$ in Figure 7).

Table 4. Cyclic Experimental Programme

\begin{tabular}{c|c|c|c|c}
\hline $\begin{array}{c}\text { Test } \\
\text { No. }\end{array}$ & $\begin{array}{c}\text { Test } \\
\text { type }\end{array}$ & Connection Type & $\begin{array}{c}\text { Connection } \\
\text { Member }\end{array}$ & Test Type \\
\hline 7 & C20018 & PTBH & FHB200A & Cyclic \\
8 & C20018 & NTBH & FHB200B & Cyclic \\
\hline 9 & C25020 & PTBH & FHB250A & Cyclic \\
10 & C25020 & NTBH & FHB250B & Cyclic \\
\hline 11 & C30025 & PTBH & FHB300A & Cyclic \\
12 & C30025 & NTBH & FHB300B & Cyclic \\
\hline
\end{tabular}

\subsection{Cyclic test results}

The hysteretic plots of lateral in-plane load vs lateral in-plane displacement for the cyclic tests are shown in Figure 9. The smaller dimension cross sections show a more stable hysteretic response and relatively achieve a larger lateral in-plane displacement during the tests. 
Tabulated results from the tests are shown in Table 4 . Test 8 terminated at 19 cycles and Test 9 terminated at 20 cycles due to testing issues in the laboratory. Tests $11 \& 12$ reached maximum actuator load capacity after 14 cycles. It should be noted that there was an issue with Test 9 as the data for the $60 \mathrm{~mm}$ cycle became corrupted; therefore the cycle jumps from $50 \mathrm{~mm}$ cycle to $70 \mathrm{~mm}$ cycle. The larger dimension cross-section sizes resist a higher load at a lower lateral in-plane frame displacement for a lower number of cycles as can be seen from Figures 9(a) \& (b). Figure 9(b) shows strain hardening of the frame, but no stiffness degradation in the response of the C30025 specimen with NTBH connection. In contrast, the PTBH C30025 specimen in Figure 9(a) shows isotropic hardening and stiffness degradation of the frame. In general, the hysteresis loops are stable and show no signs of pinching. The stiffness and strength degradation is not significant through the duration of the test. Similar results were observed by [15]. Observation of the hysteresis plots indicates the frames perform well under cyclic loading and hence seismic conditions. 
(a)

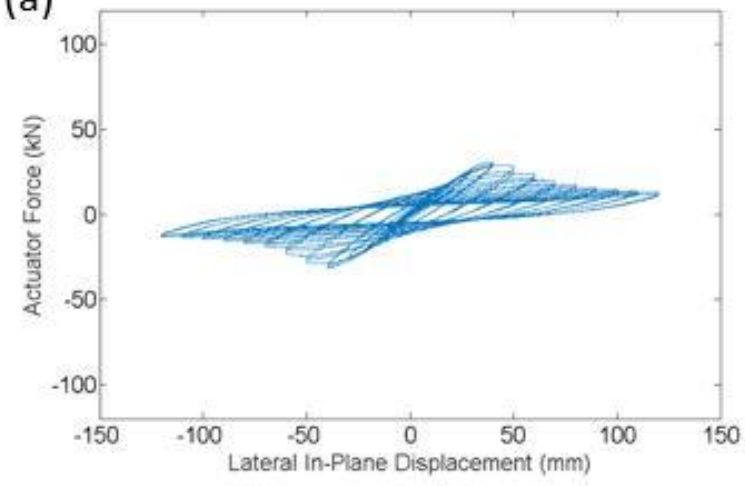

(c)

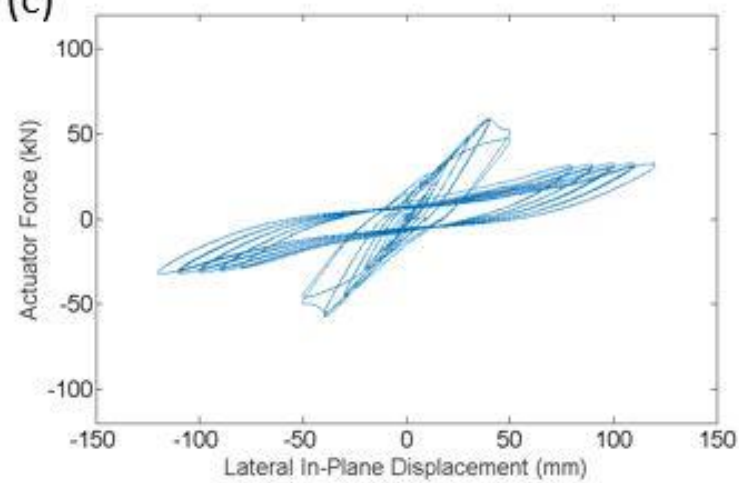

(e)

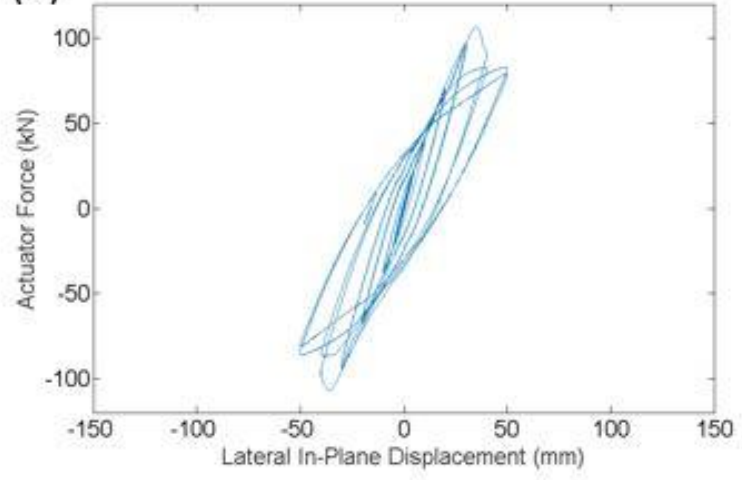

(b)

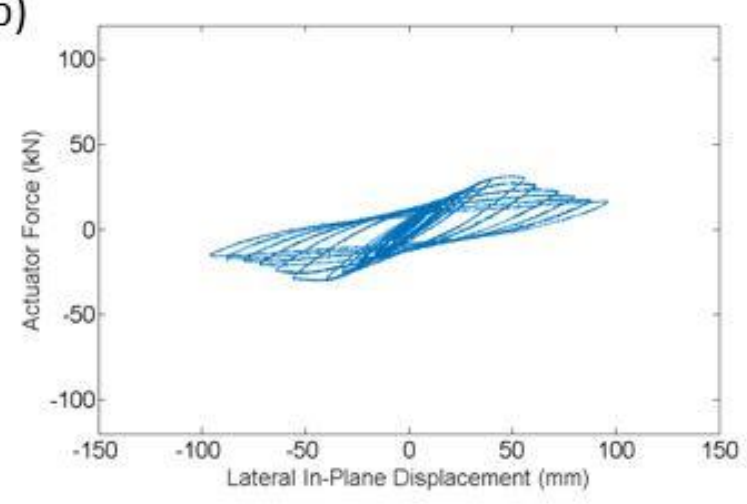

(d)

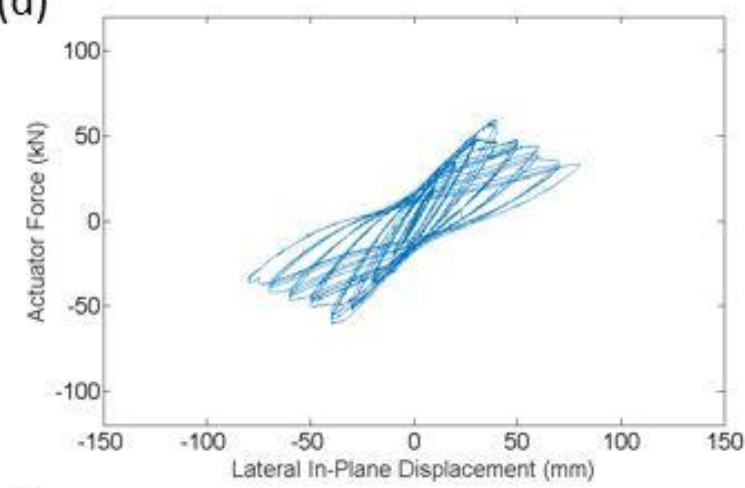

(f)

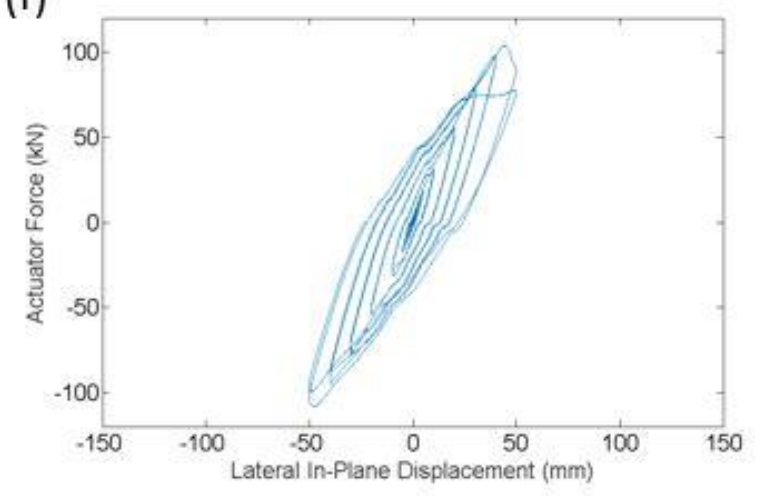

Figure 9. Hysteresis plots of lateral in-plane load vs lateral in-plane displacement for; (a) Test 7; (b) Test 8; (c) Test 9; (d) Test 10; (e) Test 11; and (f) Test 12 

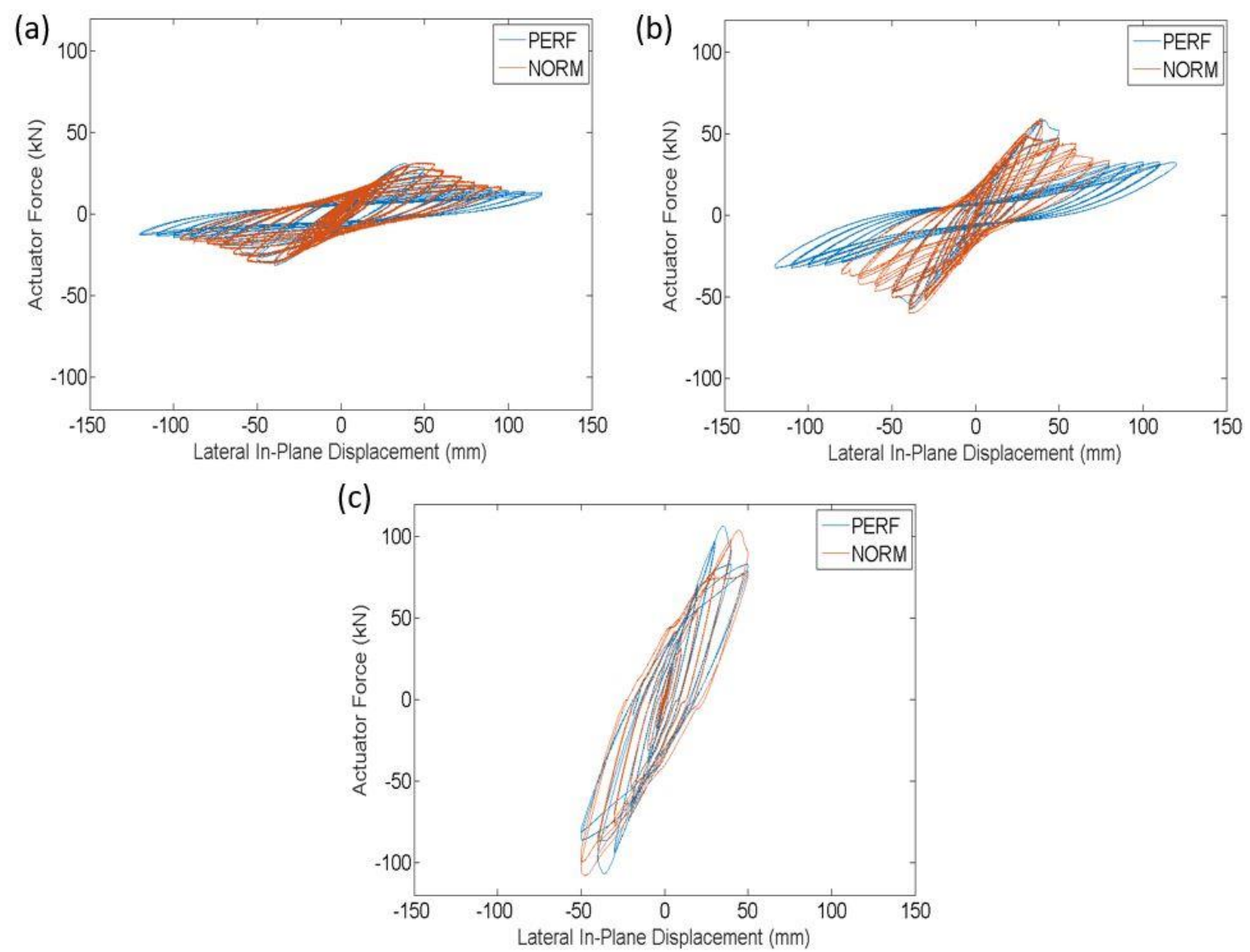

Figure 10. Hysteresis plots of lateral in-plane load vs lateral in-plane displacement for; (a) Test $7 \&$ Test 8; (b) Test $9 \&$ Test 10; and (c) Test $11 \&$ Test 12

A direct comparison between the PTBH and NTBH connections can be seen in Figure 10. In Figure 10(a), the PTBH and NTBH connections can be compared for the C20018 sections. It can be seen that the NTBH connection have slightly larger hysteresis loops (the blue lines are the PTBH tests). From a visual inspection of the plots in Figures 10 (a) \& (b) it can be seen that the C20018 and C25020 back-to-back sections had a similar hysteretic response for the NTBH and PTBH connections. However, the hysteretic response of the PTBH and NTBH connection types differed for the C30025 back-to-back sections. The NTBH connection showed clear isotropic hardening of the each of the load cycles. 

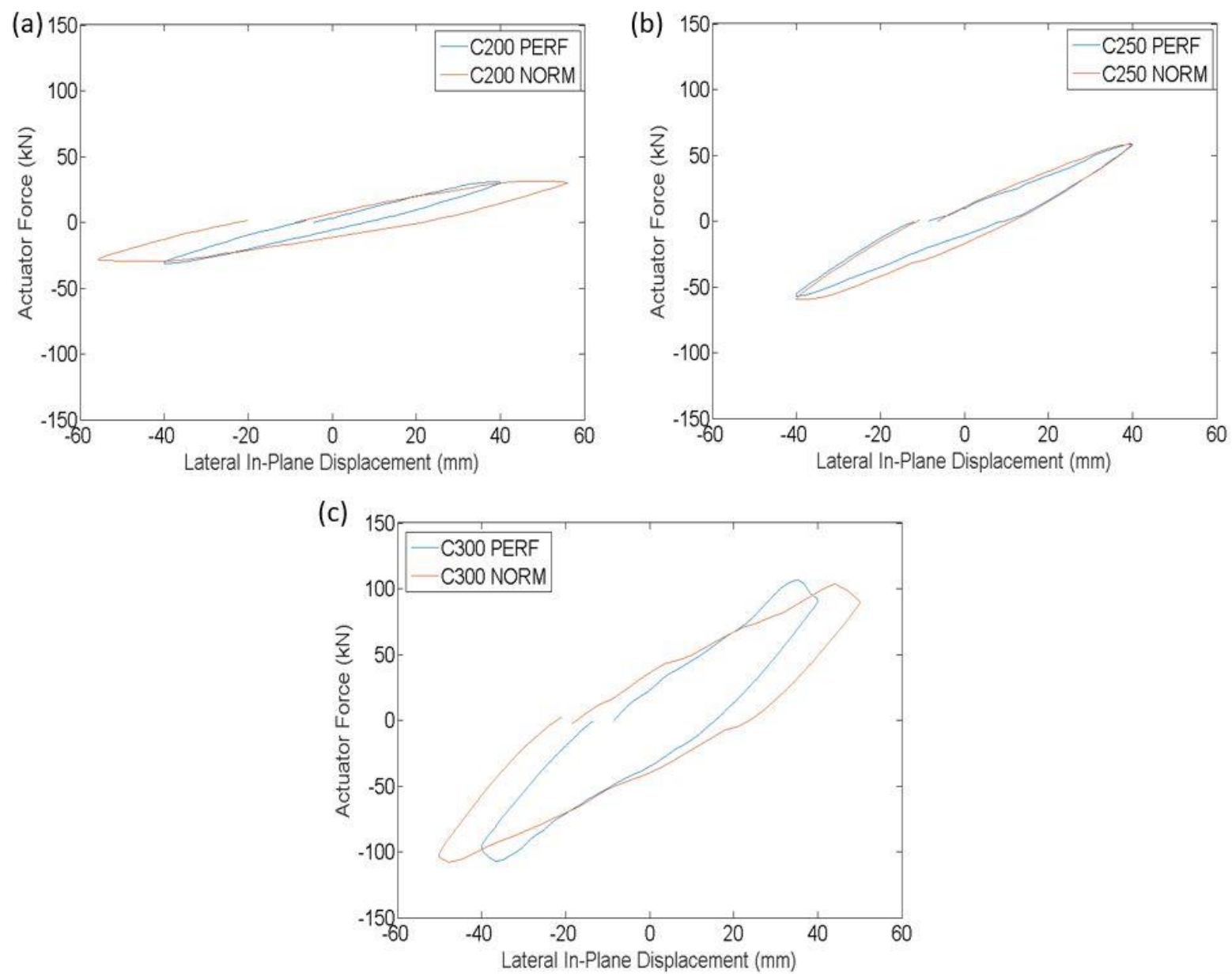

Figure 11. Comparison of load cycles at ultimate load for lateral in-plane load vs lateral in-plane displacement for PTBH and NTBH tolerance; (a) Tests 7 \& 8-C20018; (b) Tests $9 \& 10$ - C25020; and (c) Tests $11 \& 12$ - C30025

The individual cycles for the ultimate force reached in each test were extracted from the overall hysteresis and are shown in Figure 11. It can be seen that at the ultimate load cycle, NTBH connections were less stiff in comparison to the PTBH connections for all specimens. The difference is greater in the C30025 (Figure 11(c)) sections than the C20020 (Figure 11(a)) or C25020 (Figure 11(b)) sections. The NTBH connections also had larger hysteresis loops at ultimate load cycle and therefore were dissipating more energy at the ultimate load cycle.

On average, the NTBH connection was initially stiffer than the PTBH connection by 9.7\%. The smaller section size, C20018 had a larger difference in initial stiffness of $14.3 \%$ as compared to $4.8 \%$ for the larger section size, C30025 as shown in Table 5. This suggests that the torqueing of the bolts, which was the same in each test, had a greater influence on the initial stiffness of the smaller section sizes. However, this torque could potentially slip over time due to standard loading conditions or high cycle low amplitude wind loading. Figure 11 and Table 
5 taken together suggest the connection in the NTBH connection had slipped and the friction and slip resulted in a less stiff section at ultimate load but also greater ability to dissipate energy.

Table 5. Cyclic Experimental Programme

\begin{tabular}{c|c|c|c|c|c|c|c}
\hline $\begin{array}{c}\text { Test } \\
\text { No. }\end{array}$ & $\begin{array}{c}\text { Test } \\
\text { type }\end{array}$ & Connection Type & $\begin{array}{c}\text { Initial } \\
\text { Stiffness } \\
(\mathbf{N} / \mathbf{m m})\end{array}$ & $\begin{array}{c}\text { \% Difference } \\
\text { in Stiffness }\end{array}$ & $\begin{array}{c}\text { Total } \\
\text { Cycles }\end{array}$ & $\begin{array}{c}\text { Peak Disp } \\
(\mathbf{m m})\end{array}$ & $\begin{array}{c}\text { Peak Force } \\
(\mathbf{k N})\end{array}$ \\
\hline 7 & $\mathrm{C} 20018$ & PTBH & 1177.6 & - & 25 & 120 & 31.5 \\
8 & $\mathrm{C} 20018$ & $\mathrm{NTBH}$ & 1346.2 & +14.3 & 19 & 96.1 & 31.6 \\
\hline 9 & $\mathrm{C} 25020$ & PTBH & 2622.5 & - & 20 & 120.1 & 59.2 \\
10 & $\mathrm{C} 25020$ & NTBH & 2881.1 & +9.9 & 25 & 80.1 & 60.1 \\
\hline 11 & $\mathrm{C} 30025$ & PTBH & 5177.9 & - & 14 & 50.1 & 107.1 \\
12 & $\mathrm{C} 30025$ & NTBH & 5424.5 & +4.8 & 14 & 50.1 & 108.1 \\
\hline
\end{tabular}

Due to the differing number of load cycles undertaken in comparable tests, it was only possible to compare the total energy dissipation capacity directly in Tests 11 and Test 12. Therefore, the energy dissipation capacity and lateral in-plane displacement and forces were compared for each test at the equivalent highest comparable cycle achieved for each. These results are shown in Table 6. It can be seen from Table 6 that the NTBH connections had slightly higher displacement ductility (5.4\%) in comparison to the PTBH connection. The NTBH connection had a noticeably higher comparable level of average energy dissipation capacity of $22.6 \%$.

Table 6. Rationalised Cyclic Experimental Results with Equivalent Number of Cycles

\begin{tabular}{c|c|c|c|c|c|c|c|c}
\hline $\begin{array}{c}\text { Test } \\
\text { No. }\end{array}$ & $\begin{array}{c}\text { Test } \\
\text { type }\end{array}$ & $\begin{array}{c}\text { Connection } \\
\text { Type }\end{array}$ & $\begin{array}{c}\text { Equal } \\
\text { Cycle No. }\end{array}$ & $\begin{array}{c}\text { Peak } \\
\text { Disp } \\
(\mathbf{m m})\end{array}$ & $\begin{array}{c}\text { Disp. Yield } \\
\text { Ductility }\end{array}$ & $\begin{array}{c}\text { \% Difference } \\
\text { in Yield } \\
\text { Ductility }\end{array}$ & $\begin{array}{c}\text { Energy } \\
\text { Dissipation } \\
\text { (N/m) }\end{array}$ & $\begin{array}{c}\text { \% Difference } \\
\text { in Energy } \\
\text { Dissipation }\end{array}$ \\
\hline 7 & C20018 & PTBH & 12 & 96.1 & 4.4 & - & 12367 & - \\
8 & C20018 & NTBH & 12 & 96.1 & 4.6 & +4.5 & 15828 & +28.0 \\
\hline 9 & C25020 & PTBH & 20 & 80.1 & 3.9 & - & 12067 & - \\
10 & C25020 & NTBH & 20 & 80.1 & 4.1 & +5.1 & 14379 & +19.2 \\
\hline 11 & C30025 & PTBH & 14 & 50.0 & 2.9 & - & 22697 & - \\
12 & C30025 & NTBH & 14 & 50.0 & 3.1 & +6.7 & 27387 & +20.7 \\
\hline
\end{tabular}


Table 7. Cyclic vs Monotonic Experimental Programme

\begin{tabular}{c|c|c|c|c|c}
\hline $\begin{array}{c}\text { Test } \\
\text { No. }\end{array}$ & $\begin{array}{c}\text { Test } \\
\text { Specimen }\end{array}$ & Test type & $\begin{array}{c}\text { Connection } \\
\text { Type }\end{array}$ & $\begin{array}{c}\text { Experimental } \\
\text { Initial Stiffness } \\
(\mathbf{N} / \mathbf{m m})\end{array}$ & $\begin{array}{c}\text { Difference in } \\
\text { Experimental } \\
\text { Initial Stiffness (\%) }\end{array}$ \\
\hline 1 & C20018 & Monotonic & PTBH & 1204.1 & - \\
2 & C20018 & Monotonic & NTBH & 1432.7 & +18.9 \\
7 & C20018 & Cyclic & PTBH & 1177.6 & - \\
8 & C20018 & Cyclic & NTBH & 1346.2 & +14.3 \\
\hline 3 & C25020 & Monotonic & PTBH & 2584.2 & - \\
4 & C25020 & Monotonic & NTBH & 2701.9 & +4.6 \\
9 & C25020 & Cyclic & PTBH & 2622.5 & - \\
10 & C25020 & Cyclic & NTBH & 2881.1 & +9.9 \\
\hline 5 & C30025 & Monotonic & PTBH & 5063.2 & - \\
6 & C30025 & Monotonic & NTBH & 5238.1 & +3.5 \\
11 & C30025 & Cyclic & PTBH & 5177.9 & - \\
12 & C30025 & Cyclic & NTBH & 5424.5 & +4.8 \\
\hline
\end{tabular}

As can be seen in Table 7, the increase in initial stiffness of the NTBH connections is relatively similar in both the cyclic and monotonic tests for all of the specimens. The average increase in initial stiffness between the NTBH and PTBH connections is 9.4\% (C20018: 16.6\%, C25020: 7.3\% \& C30025: 4.2\%). In Table 5, the NTBH connections exhibit on average 22.6\% (C20018: 28\%, C25020: 19.2\% \& C30025 20.7\%) greater energy dissipation than the PTBH connections. The greater energy dissipation capacity is also reflected in the displacement ductility of the NTBH connections being on average 5.4\% greater than that of the PTBH connections. The increased ductility and observation in Figure 11 that the NTBH connections have a lower stiffness at ultimate load is most likely due to slipping of the connection resulting in friction and the observed greater energy dissipation and ductility.

\subsection{Visual observations and strain gauge results}

\subsubsection{Strain gauge results analysis}

Figure 12 shows plots of measured strains converted into stresses for Test 8 which was a C20018 frame with NTBH. The locations of the strain gauges around the cross-section are shown in Figure 13. The strain gauges are located on the column section $1315 \mathrm{~mm}$ up from the column base. The load cycle, at which test frame has reached a maximum horizontal load was identified and measured strains converted to stresses for this peak pushover load cycle are marked in Figure 12. In Figure 12, a negative sign represents compressive stresses and positive sign represents tensile stresses. The measured stress distribution around the channel crosssection for the peak pushover load cycle marked in Figure 12 is magnified in Figure 14. In 
Figure 14, the measured stresses are plotted for given locations along the channel cross-section (i.e. $-74.6 \mathrm{MPa}$ at $\mathrm{SG}[1] \& 154.1 \mathrm{MPa}$ at $\mathrm{SG}[6])$.

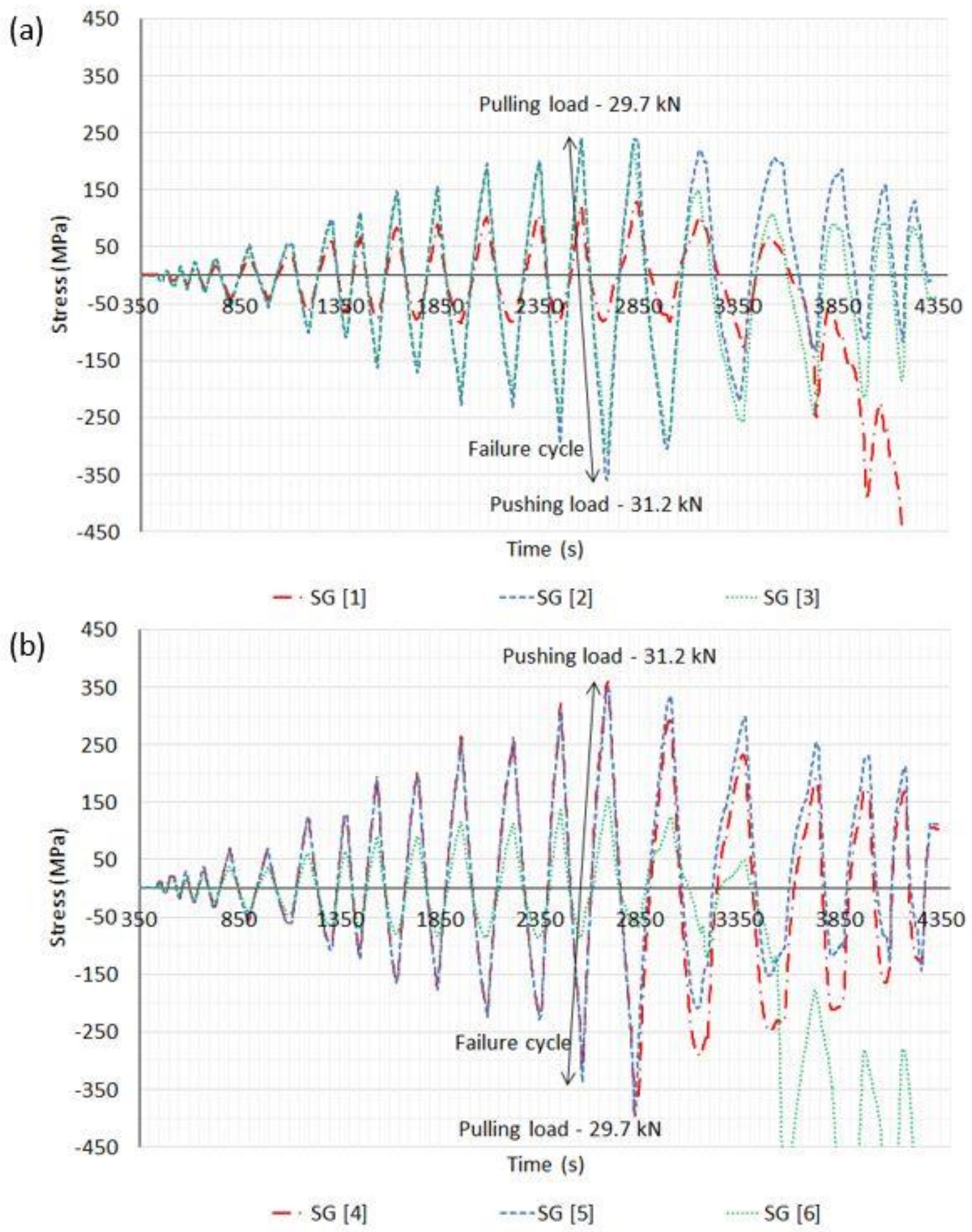

Figure 12. Strain gauge results for Test 8 (C20018 with NTBH connection) (a) SG1 \& 3 and (b) SG4 \& 6

Back-to-back built-up columns are doubly-symmetric, therefore in practical design they are often considered to behave like solid I-beams. This assumption, however, may not be correct as channels are split by the bracket [19]. In this paper, stresses have been calculated based on 
the assumptions that two separate channels are sharing the load equally. The non-linear elastic frame analysis program Robot Structural Analysis Professional 2010 [27] was used for the calculation of internal forces. For a lateral load of $29.7 \mathrm{kN}$ in the peak push load cycle, a simple beam idealisation was used to calculate reactions and bending moment diagram as shown in Figure 15. It should be noted that measured rotational stiffness of the base connection were used in the analysis.

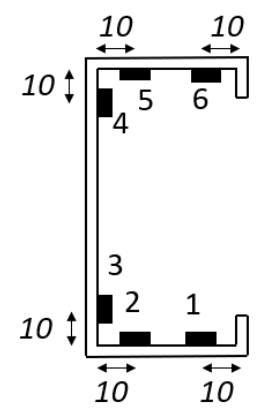

Figure 13. Location of strain gauges in cross section

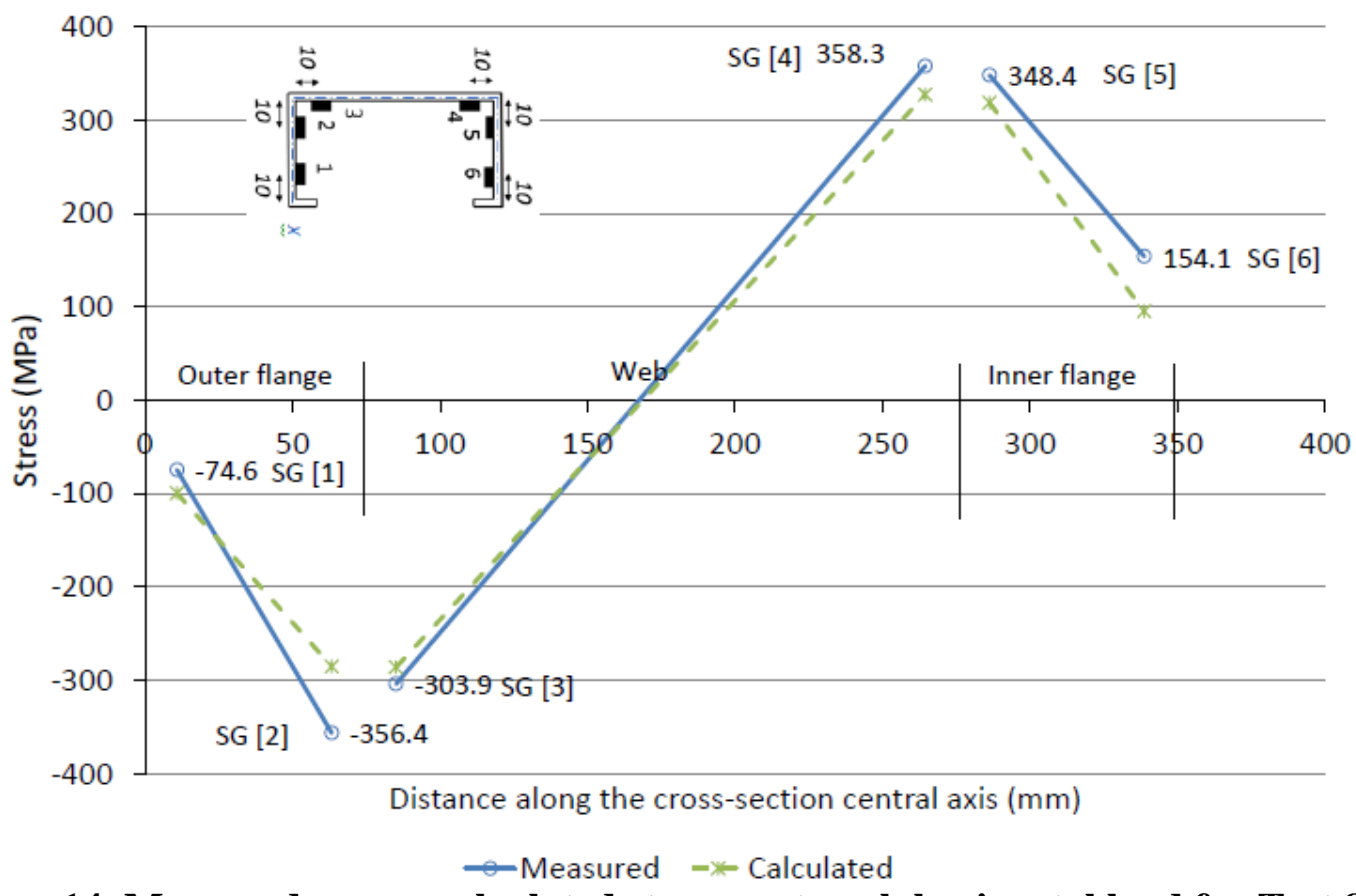

Figure 14. Measured versus calculated stresses at peak horizontal load for Test 8

The stresses for a single channel section were calculated using CUFSM v.4 open-source software [28] and are presented in Figure 16 and Table 8. The front channel of the left-hand side column is subject to a uniform tension of $\mathrm{N}=8.69 \mathrm{kN}$ (see Figure 15). This will result in the tensile stress of $13.03 \mathrm{MPa}$ (see Figure 16a and Table 8). The tensile load is not applied through the centre of gravity of the single channel (load applied via web only), therefore a minor axis bending of $0.18 \mathrm{kNm}$ is also generated $(\mathrm{Mz}=8.69 \mathrm{kN} \times 0.021 \mathrm{~m})$. The stress distribution because of this action is presented in Figure 18c. The major axis bending was 
obtained from the Figure 15 at the location of the strain gauges (1315mm up from the base) as $\mathrm{My}=9.00 \mathrm{kNm}$ and stress distribution was presented in Figure $16 \mathrm{~b}$ and in Table 8. In case of the bi-moment, the value was calculated according to the Eq.1as per [17].

$$
B_{\omega}=\frac{M_{x} \cdot \sinh (k x)}{2 k \cdot \cosh (k l / 2)}
$$

Where:

$M_{x}=0.255 \mathrm{kNm}$ - Torsional moment calculated as horizontal reaction times distance between the web and shear centre of the single channel $(0.5 \cdot 15.27 \mathrm{kN} \cdot 0.0334 \mathrm{~m})$,

$k=\sqrt{\frac{G I_{t}}{E I_{w}}}=0.253 \mathrm{~m}^{-1}-$ constant

$G=81 \mathrm{GPa}-$ Elastic modulus

$E=210 \mathrm{GPa}-$ Young's modulus

$I_{t}=689 \mathrm{~m}^{4}-$ Torsional constant for a single channel

$I_{w}=4140062875 \mathrm{~mm}^{6}-$ Warping constant for a single channel

$x=1315 \mathrm{~mm}-$ distance from the column base to the location of strain gauges

$l=2780 \mathrm{~mm}-$ Length of the beam under torsion, taken as twice the distance from the column base to the channel/bracket junction.

It should be noted that the Eq. 1 was derived for a simply supported beam subject to the torsional moment at the mid-span and fork restraints at both ends. Based on the symmetry conditions of the test frame here, it was assumed that such load and boundary conditions are very similar to those present during the Test 8 and the bi-moment is reaching the maximum at the channel/bracket junction where the maximum twist was observed. The value of the bimoment at the location of the strain gauges was calculated as $\mathrm{B} \omega=0.1607 \mathrm{kNm} 2$ and the respective stresses for different strain gauge locations are presented in Figure 16d and Table 8. The calculated longitudinal stresses at strain gauge locations for individual actions and the resultant longitudinal stresses under combined actions are presented in Table 8. It should be noted that the sign convention in Table 8 was aligned with test results and positive sign represents tensile stress and negative sign represents compressive stress.

As can be seen in Figure 14, generally good correlation between calculated and measured stresses was observed particularly in the web. In terms of the flanges, the calculated stress gradients are slightly different from the test results, but this might be explained by simplifications in analytical assumptions (i.e. perfect cross-section geometry). These 
assumptions may not represent 'true' behaviour of an imperfect thin-walled section subject to local buckling. An interesting observation is that recorded stress in the flange/lip part in compression (SG [1] $=-74.6 \mathrm{MPa}$, Table 8 ) is approximately $50 \%$ of the respectively recorded stress of the flange/lip part in tension ( $\mathrm{SG}[6]=154.1 \mathrm{MPa}$, Table 8Table). This finding is magnified in Figure 14 where measured stresses are plotted for given locations along the channel cross-section. This figure shows that both outer and inner flanges are subject to stress gradient which is significantly different from the calculated one.

Based on the analytical method, it can be concluded that stresses due to the bi-moment have the second largest contribution (after major axis bending) to the overall stresses for the C20018 frame (see Table) and therefore must be considered in the practical design. Very similar structural responses were recorded for C25020 \& C30025 portal frames.

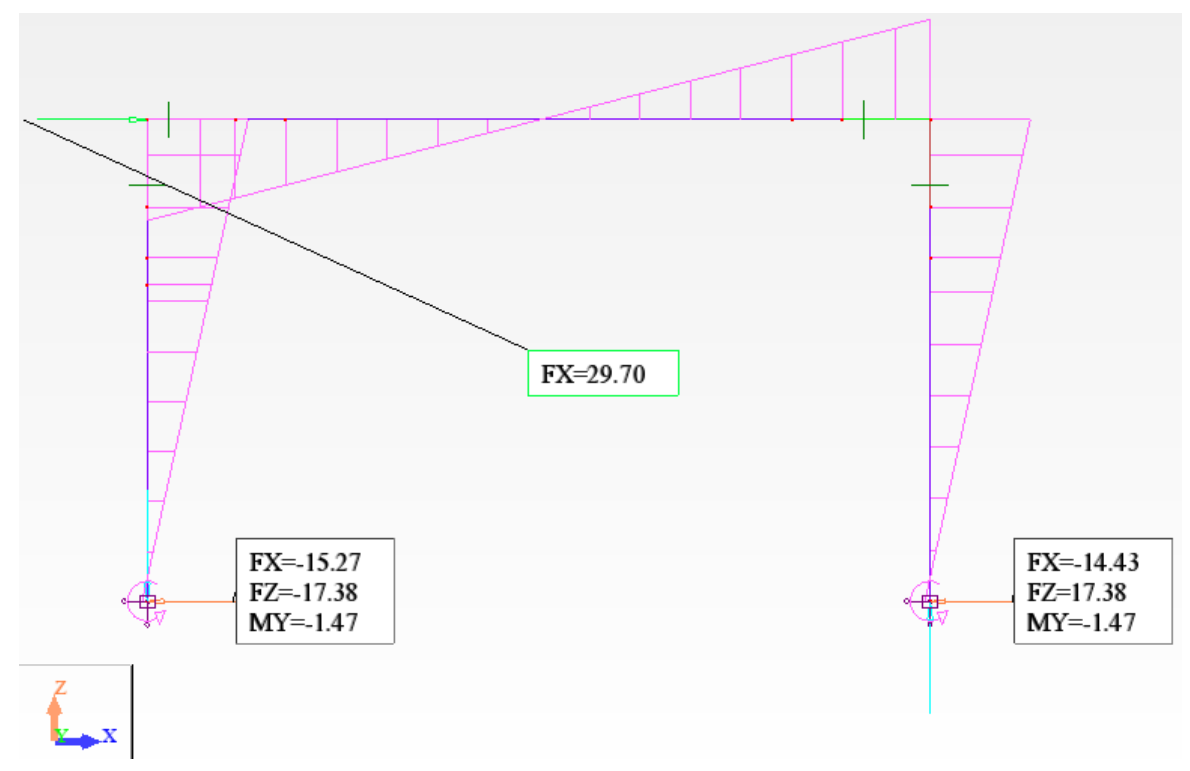

Figure15. Bending moment diagram and reactions at the peak horizontal load recorded in Test 8 [27] 
(a)

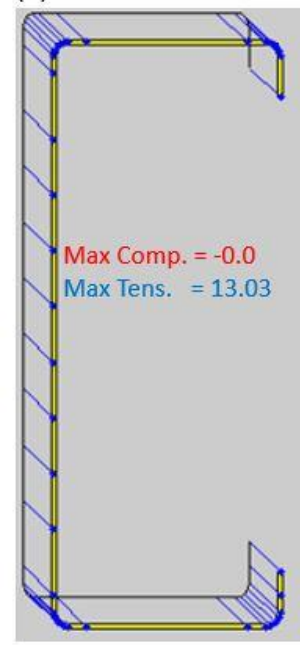

(b)

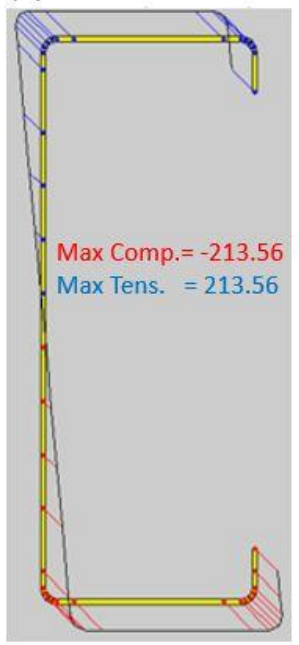

(c)

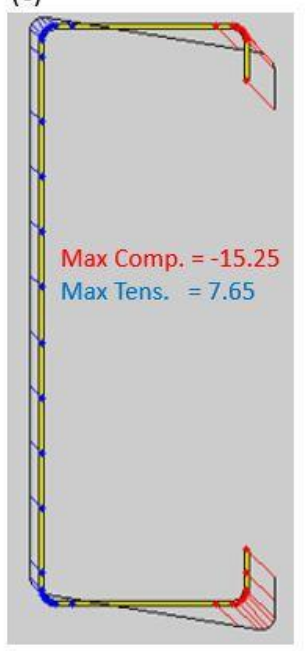

(d)

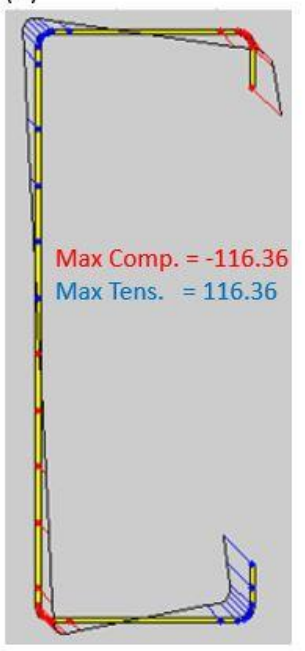

(e)

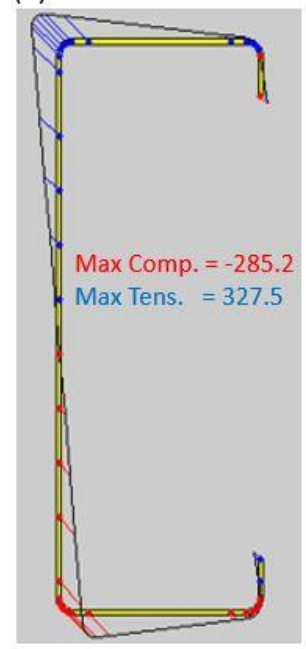

Figure 16. Longitudinal stresses imposed by; (a) uniform tension, (b) major axis bending (bottom flange in compression), (c) minor axis bending (lips in compression), (d) bi-moment (bottom flange/web in compression, and (e) superposition of stresses [28]

Table 8. Calculated stresses for the C20018 frame (standard holes tolerance) at $29.7 \mathrm{kN}$ push load

\begin{tabular}{c|c|c|c|c|c|c}
\hline \multirow{2}{*}{$\begin{array}{c}\text { Strain } \\
\text { gauge } \\
\text { locations }\end{array}$} & $\begin{array}{c}\text { Uniformed } \\
\text { tension } \\
(\mathbf{N = 8 . 6 9 k N )}\end{array}$ & $\begin{array}{c}\text { Major axis } \\
\text { bending } \\
\left(\mathbf{M}_{\mathbf{y}}=\mathbf{9 . 0 k N m}\right.\end{array}$ & $\begin{array}{c}\text { Minor axis } \\
\text { bending } \\
\left(\mathbf{M}_{\mathbf{z}}=\mathbf{0 . 1 8 k N m}\right)\end{array}$ & $\begin{array}{c}\text { Bi-moment } \\
\left(\mathbf{B}_{\boldsymbol{\omega}}=\mathbf{0 . 1 6 0 7} \mathbf{k N m}\right)\end{array}$ & $\begin{array}{c}\text { Sum of } \\
\text { stresses }\end{array}$ & $\begin{array}{c}\text { Test } \\
\text { results }\end{array}$ \\
\hline 1 & 13.03 & -213.56 & -15.25 & 116.07 & -99.7 & -74.6 \\
\hline 2 & 13.03 & -213.56 & 3.71 & -88.40 & -285.2 & -356.4 \\
\hline 3 & 13.03 & -190.42 & 7.65 & -116.36 & -286.1 & -303.9 \\
\hline 4 & 13.03 & 190.42 & 7.65 & 116.36 & 327.5 & 358.3 \\
\hline 5 & 13.03 & 213.56 & 3.71 & 88.40 & 318.7 & 348.4 \\
\hline 6 & 13.03 & 213.56 & -15.25 & -116.07 & 95.3 & 154.1 \\
\hline
\end{tabular}

\subsection{Visual inspection of test specimens}

Visually, there was no observable difference in the failure mechanism between the PTBH and NTBH failure mechanism. The failure mechanism, as can be seen in Figure 17Figure \& Figure 18, of the PTBH and NTBH moment resisting frame appears to be influenced by the bi-moment effect and not governed by the method of connection. In general, the failure mechanism consisted of local buckling of the web and flanges of the column adjacent to the haunch connection (see Figure $17 \&$ Figure 18). Tearing in the flange to web return (see Figure 19 typically followed and a similar mode of failure was reported by Sabbagh et al. 2012 [13] for 
channels with curved flanges. Based on the visual observations of the failure mechanism in the portal frame, the gravity load carrying capacity of the structure would have been severely reduced. It may be necessary to alter this failure mechanism, particularly if extending design to multi-storeys, to have the failure occur in the beam rather than column.

From visual inspection (see Figure $17 \&$ Figure 18) as well as strain gauge readings, the initial failure mechanism was a result of combined bending and bi-moment stresses causing web buckling of the section in the column. As the highest compression stresses were present at the web-to-flange junction at the column/haunch connection buckling first occurred there. When the load direction was reversed in the cycling loading almost symmetric buckles developed at the opposite corner. Cyclic loading in the post-buckling stage had continued the strain hardening process by subjecting buckled steel plates to compression/tension loads, resulting in fracture of steel. The reduction of steel ductility in the section corners due to cold working is well known and was researched by [29]. As the initial failure was a result of a local web buckling which propagated to the flange (failure cycle is shown in Figure 16), section corners were responsible for carrying the majority of the tensile/compressive stresses at the post-buckling stage. The ductility of steel at section corner was therefore reduced further due to cold working with every load cycle, resulting in fracture of steel (as can be seen in Figure 17d and Figure 19a). The fracture/tearing were mainly observed along the fold lines of the channel section (web-to-flange junction) and flange stiffener (lip) as shown in Figure 19.
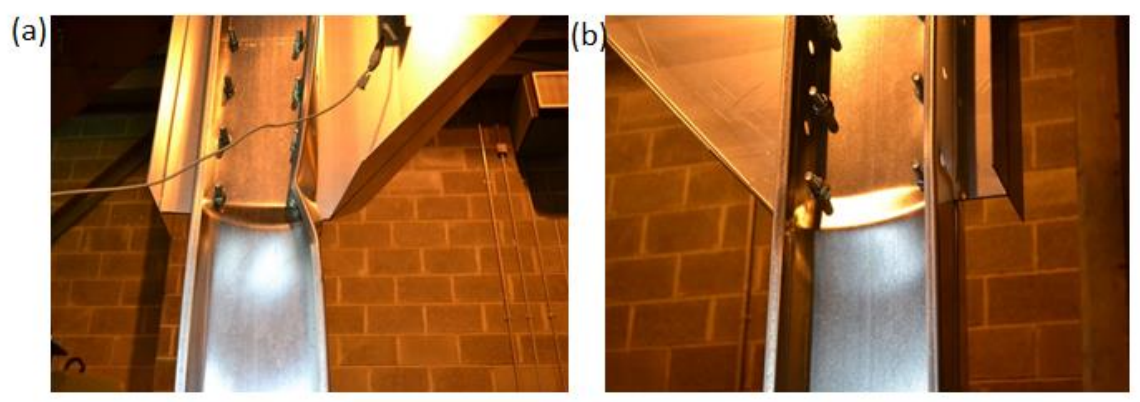

(c)

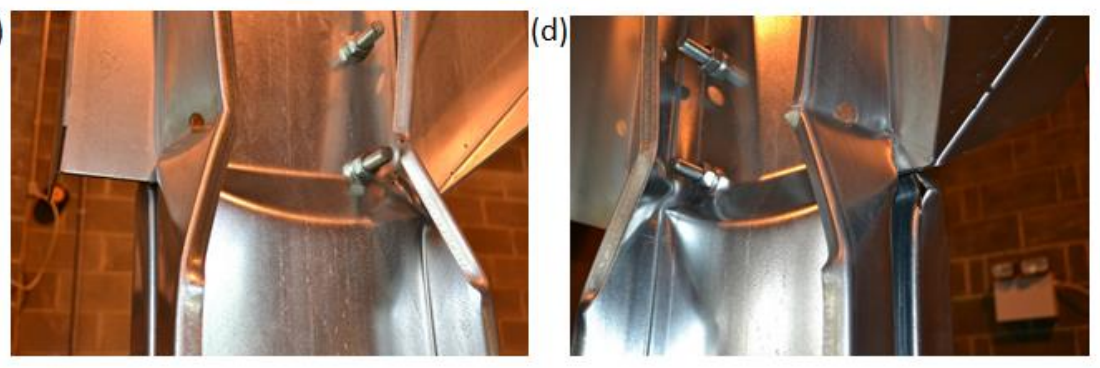

Figure 17. Photographs of Test 10 showing; (a) local buckling in left-hand side (LHS) and; (b) right-hand side column; (c) LHS column failure after test with photo taken from the left; and (d) LHS column failure after test with photo taken from the right 

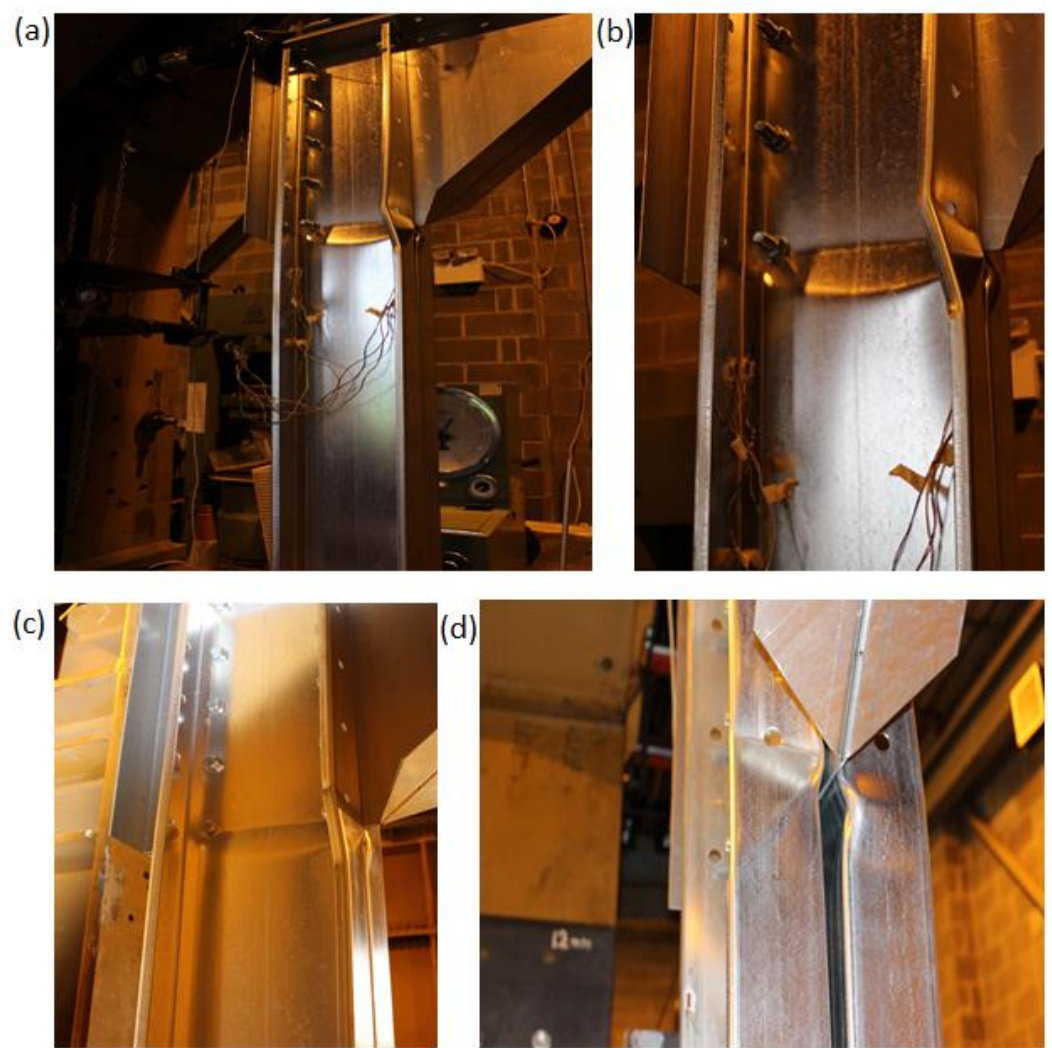

Figure 18. Photographs of Test 11 showing; (a) local buckling in left hand side (LHS) column after test; (b) close up of RHS column failure after test; (c) rear view of right hand side (RHS) column failure after test; and (d) side view of RHS column and haunch connection after test
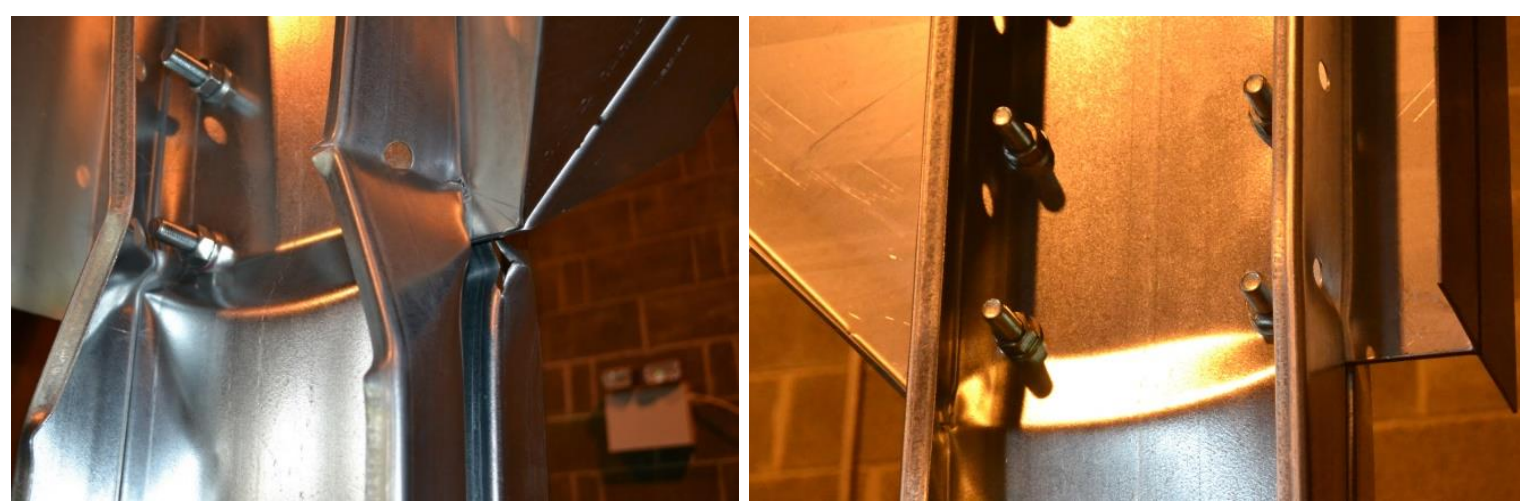

Figure 19. Close up photograph of Test 10 buckling/tearing in the section at the end of the test; (a) left-hand side column, and (b) right-hand side column

The base support detail was designed to allow rotation of the base connection, so they could be assumed as pinned connections. When base connections were tested prior to full-scale tests, the measured rotation stiffnesses were small (between $52 \mathrm{kNm} / \mathrm{rad}$ and $68 \mathrm{kNm} / \mathrm{rad}$ ), hence base support connections acted like 'perfect pins'. It was observed that base connection angles were 
not significantly deformed after tests. Almost no elongation of bolt holes was also observed once the frames were dismantled after the tests.

\subsection{Discussion \& Conclusions}

The results show that the CFS portal frame structure with either PTBH or NTBH connections performed well during cyclic testing. All of the single storey CFS moment resisting frames comprised of back to back channel sections (C20018, C25020 \& C30025) and demonstrated stable cyclic hysteresis response, good energy dissipation capacity and ductility during cyclic loading. At ultimate load, the test specimens had severely locally buckled in the columns.

The cyclic results showed that NTBH connections perform better in comparison to the PTBH connections with respect to energy dissipation capacity and ductility. The NTBH connections had on average $9.4 \%$ greater initial stiffness compared to the PTBH connections. The displacement ductility of the NTBH connections was on average $5.4 \%$ greater than that of the PTBH hole connections and the energy dissipation was on average $22.6 \%$ greater in the NTBH connections. Observations showed that the NTBH connections had lower stiffness at ultimate load in comparison to the PTBH connection. This lower stiffness at ultimate load is most likely due to slipping of the connection resulting in friction and the observed greater energy dissipation and ductility.

The initial failure mechanism was a result of combined bending and bi-moment stresses causing web buckling of the section web in the column. Initial buckling occurred at the webto-flange junction at the column/haunch connection location. The ductility of the steel in the section corners is affected by cold working and therefore cyclic loading post-buckling continued the strain hardening process resulting in fracture of steel. The fractures were mainly observed along the fold lines of the channel section (web-to-flange junction) and flange stiffener (lip) in the column section. The significant local buckling and fracture observed in the columns would result in significant reduction of the gravity load carrying capacity of the column sections. This failure mechanism would need to be addressed such that the failure would only occur in the beam and not the column, particularly if the frames were to be extended to multi-storey design.

From the analysis of strain gauge results, designers would need to be aware that stresses due to the bi-moment have a second largest contribution (major axis bending having the largest) to the overall stresses in the column sections and they should take this into account in their designs. Strain gauge results show failure is due to combined bending and bi-moment stresses, of which the bi-moment stress component accounted for $41 \%$ of the total longitudinal stresses 
at the section web. Based on the presented example, if the practical design is based on the major axis bending only, applied moment should not exceed approximately $59 \%$ of the section moment resistance.

\section{Acknowledgements}

We would like to acknowledge the technical support from the laboratory technicians at Trinity College Dublin; namely Dr Kevin Ryan, Mr David McCauley, Dr Gerard McGranaghan. We also would like to thank Capital Steel Limited for designing frames and A Steadman \& Son for providing the steel for testing. This research was supported by an Institution of Civil Engineers, Research \& Development Grant (No. 1314).

\section{References}

[1] BS EN 1998-1:2004 Eurocode 8: Design of structures for earthquake resistance - Part 1: General rules, seismic actions and rules for buildings. BS EN 1998-1:2004. BSi, United Kingdom

[2] Wrzesien AM, Lim JBP, Nethercot DA. Optimum joint detail for a general cold-formed steel portal frame. Advances in Structural Engineering 2012; 15(9): 1623-1639

[3] Lim JBP, Wrzesien, AM, Nethercot DA. Sustainable applications of cold-formed steel structures. In: Portal frames. Recent Trends in Cold-Formed Steel Construction. C. Yu. Sawston, UK, Woodhead Publishing 2016: 265-303

[4] Rondal J, Dubina D. Light Gauge Metal Structures Recent Advances. CISM International Centre for Mechanical Sciences, Springer Wien New York, 2005

[5] Gad EF, Duffield CF, Hutchinson GL, Mansella DS, Star G. Lateral performance of coldformed steel-framed domestic structures. Engineering Structures 1999; 21: 83-95

[6] Fulop LA, Dubina D. Performance of wall-stud cold-formed shear panels under monotonic and cyclic loading: Part I: Experimental research. Thin-Walled Structures, Volume 42, Issue 2, February 2004: 321-338

[7] Lin SH, Pan CL, Hsu WT. Monotonic and cyclic loading tests for cold-formed steel wall frames sheathed with calcium silicate board. Thin-Walled Structures, Volume 74, January 2014: 49-58

[8] Padilla-Llano DA, Moen CD, Eatherton MR. Cyclic axial response and energy dissipation of cold-formed steel framing members. Thin-Walled Structures, Volume 78, May 2014: 95107 
[9] Moghimi H, Ronagh HR. Performance of light-gauge cold-formed steel strap-braced stud walls subjected to cyclic loading. Engineering Structures 2009; 31: 69-83

[10] Fiorino L, Della Court G, Landolfo R. Experimental tests on typical screw connections for cold-formed steel housing. Engineering Structures 2007; 29: 1761-1778

[11] Dubina, D. Behavior and performance of cold-formed steel-framed houses under seismic action. Journal of Constructional Steel Research 2008; 64: 896-913

[12] Uang C-M, ASCE M, Sato A, Hong J-K, Wood K. Cyclic testing and modeling of coldformed steel special bolted moment frame connections. Journal of Structural Engineering 2010; 136(8): 953-960

[13] Bagheri Sabbagh A, Pilakoutas K, Mirghaderi R. Experimental work on cold-formed steel elements for earthquake resilient moment frame buildings. Engineering Structures 2012; 42: $371-386$

[14] Bagheri Sabbagh A, Pilakoutas K, Mirghaderi R. Cyclic behaviour of bolted cold-formed steel moment connections: FE modelling including slip. Journal of Constructional Steel Research 2013; 80: 100-108

[15] Li Y, Xu Z, Li Y. Investigation on seismic performance of cold-formed steel portal frames. In: 22nd international specialty conference on cold-formed steel design and construction, St Louis, Rolla, MO: Missouri University of Science and Technology 2014; 5-6 November, 633642.

[16] Kabhir MZ, Mojtabaei SM, Kargar M. Experimental and numerical investigation of lateral performance of moment-resisting frames made of cold-formed steel sections. Proceedings of International Conference on Architecture, Structure and Civil Engineering, Antalya, Turkey, Sept. 7-8; 2015, p. 1-6

[17] Dubina D, Ungureanu V, Landolfo R. Design of Cold-formed Steel Structures: Eurocode 3: Design of Steel Structures. Part 1-3 Design of cold-formed Steel Structures, Wiley; 2012 [18] BS EN 1993-1-8. Eurocode 3 - Design of steel structures. Part 1-8: Design of joints. Brussels, European Committee for Standardization; 2005

[19] Lim JBP, Hancock GJ, Clifton G, Pham C, Das R. DSM for ultimate strength of bolted moment-connections between cold-formed steel channel members. Journal of Constructional Steel Research 2016; 117: 196-203

[20] Wrzesien AM. Effect of stressed skin action on the behaviour of cold-formed steel portal frames with non-linear flexible joints and top-hat purlins. Ph.D., University of Strathclyde; 2016 
[21] Crawford, S.F. and G.L. Kulak. Eccentrically Loaded Bolted Connections. Journal of the Structural Division, ASCE, 1971. 97(ST3): p. 765-783.

[22] Zadanfarrokh F, Bryan ER. Testing and design of bolted connections in cold-formed steel sections. 11th International Specialty Conference on Cold-Formed Steel Structures, St. Louis, Missouri, USA; 1992

[23] BS EN 10346:2015. Continuously hot-dip coated steel flat products for cold forming Technical delivery conditions. Brussels, European Committee for Standardization; 2015

[24] BS EN 10002-1:2001. Metallic materials - Tensile testing. Part 1: Method of test at ambient temperature. Brussels, European Committee for Standardization; 2001

[25] SCI P212. Joints in steel construction: simple connections Ascot, UK, The Steel Construction Institute; 2009

[26] European Convention for Constructional Steelwork (ECCS) Recommended Testing Procedure for Assessing the Behaviour of Structural Steel Elements under Cyclic Loads. Publication No. 45; 1986

[27] Autodesk Inc. Autodesk Robot Structural Analysis Professional 2010 Training Manual Metric Version. 2009.

[28] Li, Z. and B.W. Schafer, Buckling analysis of cold-formed steel members with general boundary conditions using CUFSM: conventional and constrained finite strip methods, in Proceedings of the 20th International Specialty Conference in Cold-Formed Steel Structures2010: St Louis, Missouri, USA.

[29] Sloof, P.A. \& Schuster, R.M. 2000. Yield Strength Increase of Cold Formed Sections Due to Cold Work of Forming. 15th International Specialty Conference on Cold-Formed Steel Structures. St Louis, Missouri, USA. 